\title{
OCUPAÇÃO DA BACIA HIDROGRÁFICA DO RIO UNA, PERNAMBUCO/ALAGOAS, BRASIL: UMA PERSPECTIVA ARQUEOLÓGICA
}

Rúbia Nogueira de

Andrade*

Maristela Casé Costa

Cunha**
* Fundação de Apoio ao Desenvolvimento da Universidade Federal de Pernambuco FADE-UFPE; Laboratório de Arqueologia da Universidade Federal de Pernambuco - UFPE;

** Programa de PósGraduação em Tecnologia Ambiental do Instituto de Tecnologia de Pernambuco (ITEP/OS)
RESUMO: Na busca pela compreensão da ocupação humana no território brasileiro, as bacias hidrográficas constituem importantes áreas de estudo para a Arqueologia. Com base na identificação dos registros arqueológicos da bacia hidrográfica do rio Una, localizadas entre os estados de Pernambuco e Alagoas, Brasil, esse artigo objetivou contextualizar cronologicamente os sítios e ocorrências na região. $O$ estudo permitiu a identificação de registros arqueológicos decorrentes de pesquisas arqueológicas realizadas entre os anos de 1970 e 2015, em trabalhos voltados tanto para fins acadêmicos quanto empresariais. Os dados obtidos permitiram o estabelecimento de um panorama inicial da ocupação da referida bacia, a partir dos vestígios arqueológicos associados ao período pré-histórico e histórico.

Palavras-chave: Sítios arqueológicos; Hidrografia; Povoamento; Rio Una.

ABSTRACT: In the quest for understanding human occupation in Brazil, watersheds are important areas of study in Archaeology. Based on the identification of archaeological records of Una River basin, located in the states of Pernambuco and Alagoas, Brazil, this article aimed to contextualize chronologically sites and events of the region. The study allowed the identification of archaeological records pertaining to archaeological surveys conducted between 1970 and 2015 in papers focused on both academic purposes and the business. Also resulted in an initial overview of the occupation of that basin where it was possible to reconstruct part of information about the settlement of the region, from archaeological remains associated with prehistoric and historic period.

Key words: archaeological sites; hydrography; population; Una River. 


\section{Introdução}

No contexto da busca pela compreensão da ocupação do atual território brasileiro, as regiões que integram parte de uma bacia hidrográfica apresentam potencial arqueológico diferenciado, devido à relação direta de sobrevivência do homem com a disponibilidade de água potável. Caldarelli ressalta que a proximidade de fontes de água constitui-se um fator fundamental para os assentamentos humanos. No período pré-colonial as bacias hidrográficas foram rotas importantes na migração e expansão dos grupos indígenas e, no período histórico, os rios foram rotas fundamentais no processo de penetração do colonizador ao interior do território brasileiro Caldarelli, 2012).

$\mathrm{Na}$ atualidade, à medida que a sociedade necessita utilizar novos espaços geográficos para seu desenvolvimento socioeconômico, muitas áreas de potencial arqueológico são diretamente afetadas. No que se refere às bacias hidrográficas, empreendimentos como hidroelétricas, barragens, rodovias, linhas de transmissões, resorts, entre outros, estão sendo implantados em variadas regiões. Esses empreendimentos são potencialmente causadores de danos ao patrimônio arqueológico. Caldarelli (1991) enfatiza a necessidade de se considerar, no âmbito dos estudos em bacias hidrográficas, os fatores antrópicos e físicos como responsáveis pela degradação do patrimônio arqueológico.

A temática relacionada a Arqueologia em bacias hidrográficas vem sendo estudada no Brasil a partir de pesquisas pontuais, que estão contribuindo para a compreensão do processo de ocupação do território brasileiro. Os trabalhos arqueológicos, em sua maioria, tratam da caracterização de áreas específicas inseridas em bacias hidrográficas (Schmitz, 2000; Kashimoto; Martins, 2004; Morales, 2007; Lino, 2007). Pesquisas de cunho acadêmico (Schmitz, 2000; Amaral, 2007; Brito, 2011) e, principalmente àquelas voltadas para estudos técnicos ambientais, em decorrência da implantação de empreendimentos, foram identificados em regiões de bacias hidrográficas (Kashimoto e Martins, 2000; Lino, 2007; Morales, 2007; Albuquerque, Lucena e Nogueira, 2011).

Com foco acadêmico, Schmitz (2000) apresenta resultados concernentes ao povoamento préhistórico do Pantanal do rio Paraguai. Amaral (2007) realizou estudo com foco em registros rupestres na bacia do rio Ipanema em Pernambuco, no contexto da geopaisagem. Brito (2011) estudou os registros de gravuras rupestres nas bacias dos rios Espinharas, Sabugi, Quipauá e Barra Nova na região do Seridó, no estado do Rio Grande do Norte. No âmbito da arqueologia preventiva, o estudo como o realizado por Lino (2007) na bacia do rio Araranguá, em Santa Catarina, buscou compreender a ocupação Guarani na região a partir da localização de sítios filiados à Tradição Guarani. Morales (2007) realizou pesquisa no médio curso do rio Tocantins em decorrência da implantação Usina Hidroelétrica Lajeado. Albuquerque, Lucena e Nogueira. (2011) realizaram estudo técnico em uma pequena central hidroelétrica no Rio Sirinhaém, em Pernambuco.

A bacia hidrográfica do rio Una se destaca no âmbito estadual, com sua economia baseada principalmente no comércio, agricultura e pecuária. Localizada na parte sul do estado de Pernambuco e norte de Alagoas, abrange as regiões fisiográficas do Litoral, Zona da Mata e 
Agreste. Entre os anos de 2010 e 2011, ocorreram grandes cheias na região do Una acarretando grandes prejuízos sociais, ambientais e econômicos (Itep, 2011b). Estudos científicos indicam a tendência do aumento da vazão do rio Una para o ano de 2020, o que acarretará impactos ambientais, econômicos e sociais na área (Albuquerque; Galvíncio, 2010), inclusive para o patrimônio arqueológico da região. As primeiras pesquisas arqueológicas realizadas em pontos específicos da bacia do rio Una ocorreram em fins da década de 1960 e início de 1970 (Albuquerque; Alves, 1983; Aguiar; 1986).

Os estudos no território que abrange a bacia do rio Una vêm contribuindo para o entendimento da ocupação humana na região, evidenciando o seu potencial arqueológico. Em decorrência das enchentes ocorridas na região, estudos técnicos voltados para o licenciamento ambiental de barragens foram realizados na área de abrangência da bacia (Itep, 2011a, b, c, d) e obtiveram resultado na identificação de novas descobertas arqueológicas. $O$ presente artigo visa à contextualização da ocupação da bacia do Una, com base nos registros de sítios e ocorrências arqueológicas identificados na área em questão.

\section{Material e métodos}

Para realização da presente pesquisa, considerou-se como área de estudo a bacia hidrográfica do rio Una, localizada entre estados de Pernambuco e Alagoas, no nordeste brasileiro, entre 0817'14" e 085'28'S, e 035-07'48" e 03642'10”W. Compreende as mesorregiões pernambucanas da Mata e Agreste, bem como o Leste Alagoano (Figura 1). O rio Una nasce no município de Capoeiras, em Pernambuco, apresentando sentido Oeste-Leste e extensão de $255 \mathrm{~km}$. Sua bacia abrange o território de 49 municípios (Condepe/Fidem, 2006), ocupando uma área de $6.740,31 \mathrm{~km}^{2}$, onde $6.262,78 \mathrm{~km}^{2}$ estão inseridos no estado de Pernambuco (Apac, 2014).

Os procedimentos utilizados para a composição do presente estudo corresponderam a levantamento de fontes primárias e secundárias, onde se buscou identificar os sítios e ocorrências arqueológicas existentes nos municípios que abrangem a área da bacia do rio Una. As pesquisas foram realizadas entre os anos de 2012 e 2015.

A aquisição de dados secundários foi realizada a partir de consulta ao Cadastro Nacional de Sítios Arqueológicos (CNSA) do Instituto do Patrimônio Histórico Artístico Nacional (Iphan), instituição responsável pela proteção do patrimônio arqueológico nacional (Brasil, 1961); e ao seu acervo físico, nas superintendências localizadas em Recife-PE e Maceió-AL, por meio de consulta a relatórios técnicos e acadêmicos. De forma complementar, foi acessada a base de dados do Laboratório de Arqueologia da UFPE, instituição de pesquisa que atua na área, desde fins da década de 1960 e publicações disponibilizadas na web.

Em se considerando que toda e qualquer evidência constitui documentação material relativa à ocupação da área em estudo (Holder; Orton, 1990), ainda que em diferentes níveis de complexidade, buscou-se identificar o máximo de informações acerca de evidências arqueológicas, sejam elas classificadas como sítios ou simples ocorrências de material arqueológico. Em relação aos sítios identificados no cadastro do Iphan, os mesmos serão 
referenciados com o número da ficha de registro, precedido da sigla CNSA e do Estado (CNSA no PE00000). Os demais sítios e/ou ocorrências serão referenciados com a denominação constante na documentação consultada.

Figura. 1- Mapa de localização da bacia hidrográfica do rio Una, evidenciando as mesorregiões abrangidas pela área de estudo. Fonte: ITEP, 2014.

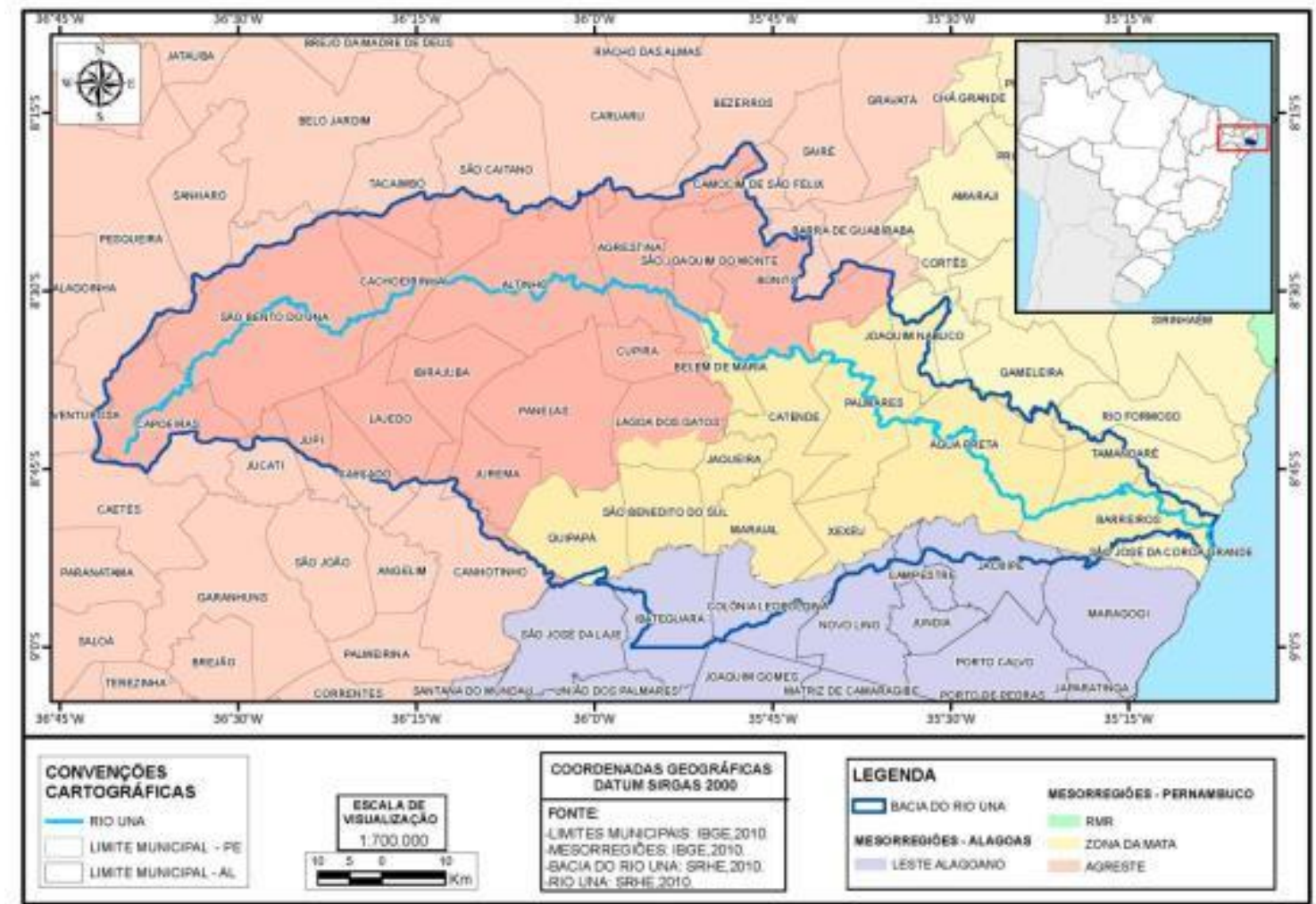

As fontes primárias utilizadas constituíram a documentação produzida durante reconhecimento realizado em parte dos sítios arqueológicos identificados nas fontes secundárias. Nesta etapa buscou-se registrar fotograficamente e plotar os sítios com aparelho GPS (Global Position System), com intuito de verificar a situação atual de preservação; bem como adquirir ou complementar dados não disponibilizados no levantamento de fontes secundárias.

Os dados obtidos neste estudo foram inseridos em planilha do Microsoft Excel 2010 e sistematizados a partir de campos pré-definidos, possibilitando uma análise cronológica e tipológica dos registros. Para fins analíticos foram consideradas as categorias pré-histórica e histórica dos vestígios, aqueles com ambas as classificações foram adicionados aos dois campos. Por fim, objetivando a visualização cartográfica dos dados, foi utilizado o software ArcGis para elaboração de mapas de ocorrência dos registros pré-históricos e históricos dos municípios que integram a bacia do Una. 


\section{Resultados e discussão}

Segundo Martin (2005), a periodização é utilizada com intuito de compreender a evolução cultural de uma sociedade. No caso do presente estudo, a análise dos dados de sítios e demais vestígios arqueológicos,realizada a partir da sistematização e visualização cartográfica das informações, possibilitou a elaboração de um panorama atual dos resultados obtidos com pesquisas realizadas na bacia hidrográfica do rio Una. Dessa forma, foi possível contextualizar os registros em dois macros períodos de tempo, conforme observado a seguir.

\section{Ocupação pré-histórica}

Em relação ao período pré-colonial, a recomposição da ocupação da área foi dificultada, sobretudo, por óbices no que se refere às informações relativas a cronologia dos vestígios arqueológicos. O levantamento de dados acerca dos registros arqueológicos da Bacia possibilitou apenas a identificação de datações obtidas em cinco sítios pré-coloniais, onde duas delas apresentam vestígios cerâmicos indígenas compatíveis com o período histórico (Quadro 1) ${ }^{1}$. Dos registros contidos no CNSA/IPHAN apenas uma ficha continha informações relativas à cronologia (CNSA no PE00118).

Quadro. 1- Cronologia dos sítios pré-coloniais identificados na bacia do rio Una. Fonte: CNSA-Iphan / Brasil Arqueológico, 2015.

\begin{tabular}{|l|l|l|l|l|l|}
\hline \multicolumn{1}{|c|}{ SítIO } & \multicolumn{1}{|c|}{ TIPO } & \multicolumn{1}{|c|}{ MUNICÍPIO-UF } & \multicolumn{1}{c|}{ DATAÇÃo } & \multicolumn{1}{c|}{$\begin{array}{l}\text { CRONOLOGIA AD } \\
\text { (INTERVALO) }\end{array}$} & \multicolumn{1}{c|}{ MÉTODO } \\
\hline $\begin{array}{l}\text { Peri-Peri I (CNSA } \\
\text { no PE00118) }\end{array}$ & $\begin{array}{l}\text { Matacão com } \\
\text { pinturas rupestres }\end{array}$ & Venturosa-PE & $\begin{array}{l}1760+/-160 \\
\text { anos BP }\end{array}$ & $\begin{array}{l}\text { Entre os anos de } 30 \\
\text { e } 350\end{array}$ & Radiocarbono \\
\hline $\begin{array}{l}\text { Peri-Peri I (CNSA } \\
\text { no PE00118) }\end{array}$ & $\begin{array}{l}\text { Matacão } \\
\text { pinturas rupestres }\end{array}$ & Venturosa-PE & $\begin{array}{l}2030+/-50 \text { anos } \\
\text { BP }\end{array}$ & $\begin{array}{l}\text { Entre os anos de - } \\
130 \text { e -30 }\end{array}$ & Radiocarbono \\
\hline PE0493 LA/UFPE & $\begin{array}{l}\text { Cerâmico } \\
\text { (Tupiguarani) }\end{array}$ & Água Preta-PE & $770+/-90$ anos & $\begin{array}{l}\text { Entre os anos de } \\
1150 \text { e } 1330\end{array}$ & Termoluminescência \\
\hline PE 0079 LA/UFPE & $\begin{array}{l}\text { Cerâmico } \\
\text { (Tupiguarani) }\end{array}$ & Quipapá-PE & $270+/-30$ anos & $\begin{array}{l}\text { Entre os anos de } \\
1710 \text { e } 1770\end{array}$ & Termoluminescência \\
\hline PE 0081 LA/UFPE & $\begin{array}{l}\text { Cerâmico } \\
\text { (Tupiguarani) }\end{array}$ & Quipapá-PE & $255+/-25$ anos & $\begin{array}{l}\text { Entre os anos de } \\
1732 \text { e } 1782\end{array}$ & Termoluminescência \\
\hline PE 0646 LA/UFPE & $\begin{array}{l}\text { Cerâmico } \\
\text { (Tupiguarani) }\end{array}$ & $\begin{array}{l}\text { Joaquim Nabuco- } \\
\text { PE }\end{array}$ & $335+/-40$ anos & $\begin{array}{l}\text { Entre os anos de } \\
1637 \text { e } 1717\end{array}$ & Termoluminescência \\
\hline
\end{tabular}

A maior parte dos vestígios pré-coloniais da bacia do rio Una está localizada na mesorregião Agreste, correspondendo a $58,7 \%$ (37) do total estudado, seguido de $31,7 \%$ (20) na Mata Pernambucana e $9,5 \%$ (6) no Leste Alagoano. Tais registros correspondem a sítios e ocorrências relacionados a vestígios rupestres, líticos e cerâmicos.

Em relação aos sítios com registros rupestres, a bibliografia relata a presença de painéis na região do semiárido nordestino (Martin, 2005). De forma análoga, os resultados da pesquisa na bacia do rio Una indicam a ocorrência de registros rupestres na região do Agreste. A única

\footnotetext{
${ }^{1}$ Datações: BP (Before Present) e AP (Antes do Presente) constituem siglas utilizadas mundialmente nos cálculos de datações, tomando como referência o ano de 1950; ano em que se obteve a primeira datação radiocarbônica por Willard Frank Libby, na Universidade de Chicago (Martin, 2005, p.75). As datações com base no ano de 1950 correspondem a idades não calibradas. Neste artigo optou-se por utilizar o intervalo da idade calibrada, ou seja, com base no Anno Domini (AD). Contudo, as citações diretas foram mantidas da forma como grafadas no texto de origem.
} 
exceção corresponde ao registro de sítio caracterizado por gravuras rupestres, denominado Pedra do Coração (CNSA no PE00342), localizado em Belém de Maria, na região da Mata Pernambucana. Este sítio rupestre é composto por duas gravuras em rocha associada, provavelmente, à Tradição Geométrica, estando localizados no leito do rio Una (Zanettini, Symanski e Moraes, 2009).

No Agreste Pernambucano se encontra o sítio com a cronologia mais recuada de toda a bacia do Una. O sítio Peri-Peri I (CNSA no PE00118) corresponde a uma área de matacões com arte rupestre e foi classificado como pertencente à Tradição Agreste. Esta Tradição ocorre na região Nordeste, com datações que chegam a 5.000 +/- 110 anos BP, no sudeste do Piauí (Martin, 2005). Em Pernambuco, pesquisas acadêmicas voltadas para registros de sítios rupestres, entre décadas de 1970 e 1980, resultaram na identificação de caraterísticas ambientais e estilísticas recorrentes em áreas com pinturas em rocha na região, que colaboraram para a definição da referida Tradição (AGUIAR, 1986; LUFT, 1990). O sítio Peri-Peri I, em Venturosa, Pernambuco, apresentou datações de 2.030 +/- 50 anos BP e 1.760 +/- 160 anos BP, a partir da análise radiocarbônica de vestígios orgânicos de duas fogueiras (Martin, 2005).

A escavação do sítio revelou uma ocupação mais antiga por caçadores, que produziam artefatos de pedra e tintas utilizadas no painel no local; seguida de uma ocupação mais recentes com restos de lascamento de material lítico, fragmentos de cerâmica com acabamento escovado e ossos de fauna de pequeno porte (Martin, 2005). Segundo Luft (1990), Peri-Peri I, II e Morro dos Ossos correspondem a um único sítio, embora tenham sido cadastrados separadamente na base de dados do Iphan.

Em 2013, o sítio arqueológico Peri-Peri foi documentado pela equipe do Laboratório de Arqueologia da UFPE, em função de levantamento para a composição de estudo ambiental da Barragem Venturosa. Na ocasião foi possível realizar documentário fotográfico e georreferenciar o local (Figura 2). Durante atividades foi identificado fragmento de material cerâmico próximo ao painel rupestre, que se encontra preservado. Contudo, foi constatado que a área do entorno do sítio é utilizada para extração de pedras. Tal fato evidencia a necessidade de ações voltadas para a preservação desse patrimônio arqueológico.

Cabe ressaltar, que o território do município de Venturosa abrange duas bacias hidrográficas, a do Una e do Ipanema, estando o sítio Peri-Peri I inserido na área desta última. No mesmo município foram registrados outros sítios da Tradição Agreste, onde a Pedra do Tubarão e o Cemitério do Caboclo foram escavados (Luft, 1990; Martin, 2005; Amaral, 2007). Após as pesquisas realizadas no local, a Pedra do Tubarão e o Cemitério do Caboclo também foram considerados um único sítio (Luft, 1990). Os pesquisadores concluíram que os grupos humanos da Tradição Agreste eram caçadores-coletores e que as áreas não correspondiam a locais de habitação, mas poderiam ter sido utilizadas como acampamento temporário. 
Figura. 2- Sítio arqueológico Peri-Peri II, Venturosa-PE. No local foi documentado fragmento de cerâmica e matacão com inscrições rupestres. Fonte: Acervo Arqueolog Pesquisas, 2013.

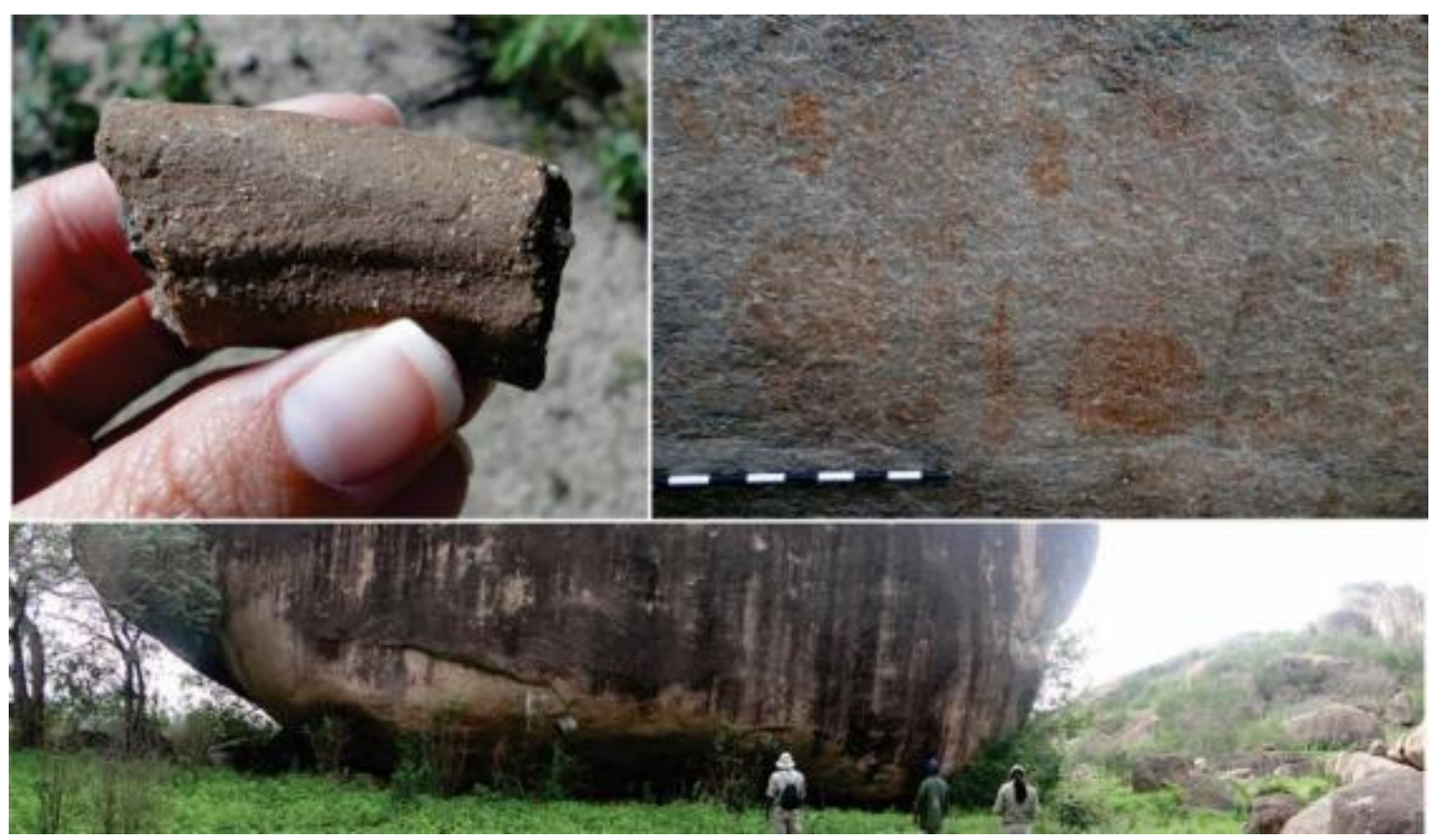

No município de São Bento do Una foi identificado um sítio com ocorrência de pinturas rupestres associado à Tradição Agreste. O sítio Pedra Comprida ou PE-B-17 (CNSA no PE00152), foi identificado em área de várzea com matacões. Em dois dos matacões existentes no local encontram-se pinturas rupestres associadas a Tradição Agreste, estilo Cariris Velhos. Em 2013, o mesmo foi documentado por pesquisadores do Laboratório de Arqueologia da UFPE, em função da realização de estudos ambientais para implantação da Barragem de São Bento do Una, onde foram constatadas depredações em painel com registros rupestres (Figuras 3 e 4). A prospecção na área do sítio permitiu à aquisição das coordenadas geográficas, uma vez que, o registro do sítio foi realizado em 1986, período que não se dispunha de aparelho GPS. Nos arredores dos painéis existe uma pedreira em funcionamento. A atividade representa um risco à integridade do sítio Pedra Comprida.

Treze sítios com pinturas rupestres, sem filiação cultural definida, foram identificados. Dez no município de Caruaru: PE 21-Ca (CNSA no PE00013 e PE00136), PE 22-Ca (CNSA no PE00137), PE 23-Ca (CNSA no PE00019) e PE 24-Ca (CNSA no PE00014), PE 25-Ca (CNSA no PE00015), Pedra da Caveira (CNSA no PE00199), Pedra da Figura (CNSA no00200), Pedra da Melancia I (CNSA noPE00206), Melancia II (CNSA no PE00207) e Cachorro I (CNSA no PE00222). Dois em São Caitano: PE 27-Im (CNSA no PE00054 e PE00178) (Figura 5) e PE 0742 LA/UFPE, conhecido como Serra do Zumba. E um em Calçado: registrado como PE0743LA/UFPE ou Pedra dos Mocós, que se encontra em processo do cadastro no Iphan (Albuquerque et al., 2013). Os sítios de São Caitano e Calçado foram documentados em 2013 por pesquisadores do Laboratório de Arqueologia da UFPE, os mesmos encontram-se preservados. No acervo do referido Laboratório foi identificado decalque das pinturas contidas no painel em papel celofane, elaborado durante o registro do sítio na década de 1970 (Figura 6). 
Figura. 3- Sítio arqueológico Pedra Comprida (CNSA no PE00152), município de São Bento do Una. Fonte: Acervo Laboratório de Arqueologia da UFPE, 2013.

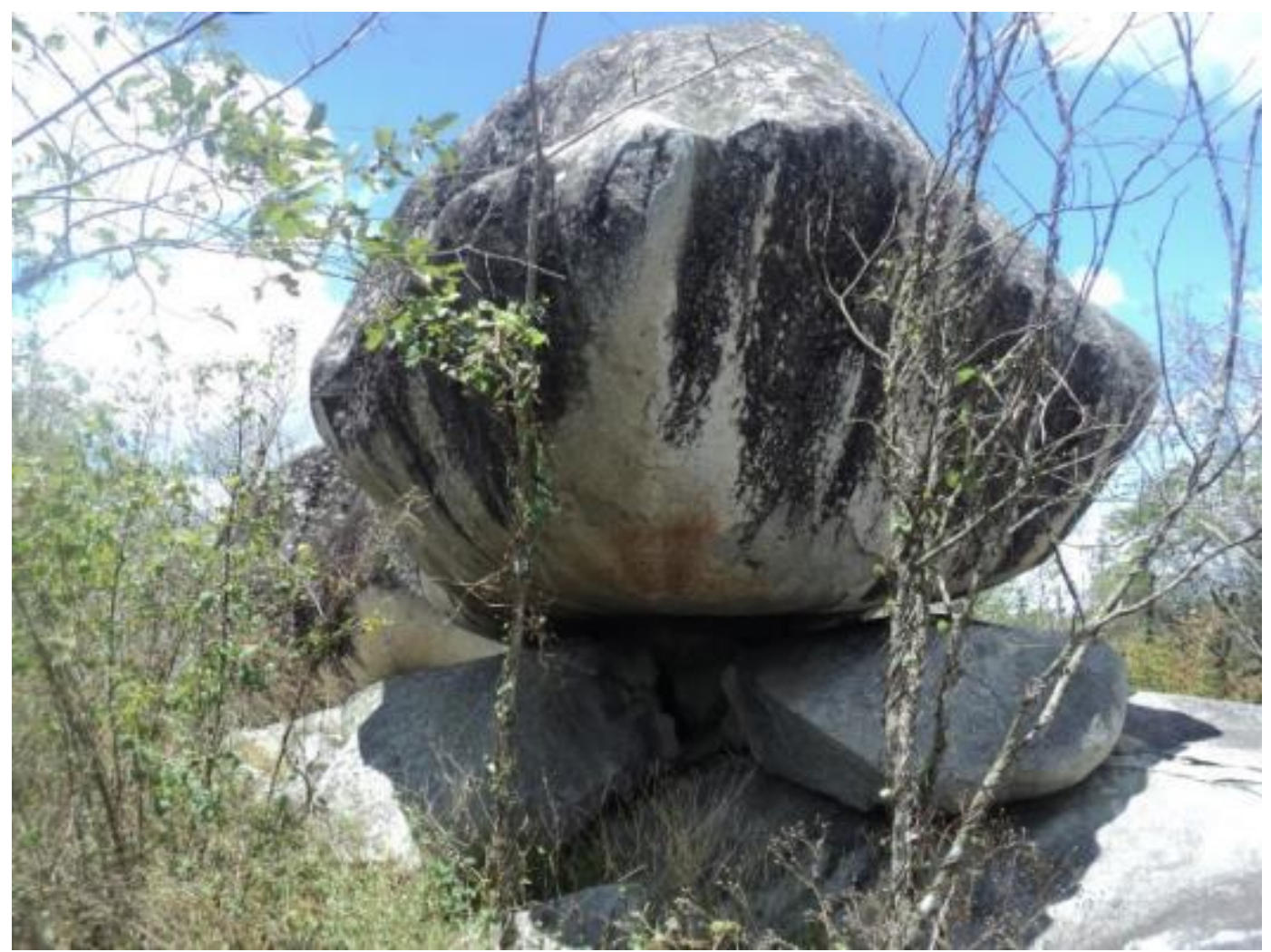

Figura. 4- Depredação do sítio arqueológico Pedra Comprida (CNSA no PE00152). Gravura recente talhada na pedra sobre uma das pinturas. Fonte: Acervo Laboratório de Arqueologia da UFPE, 2013.

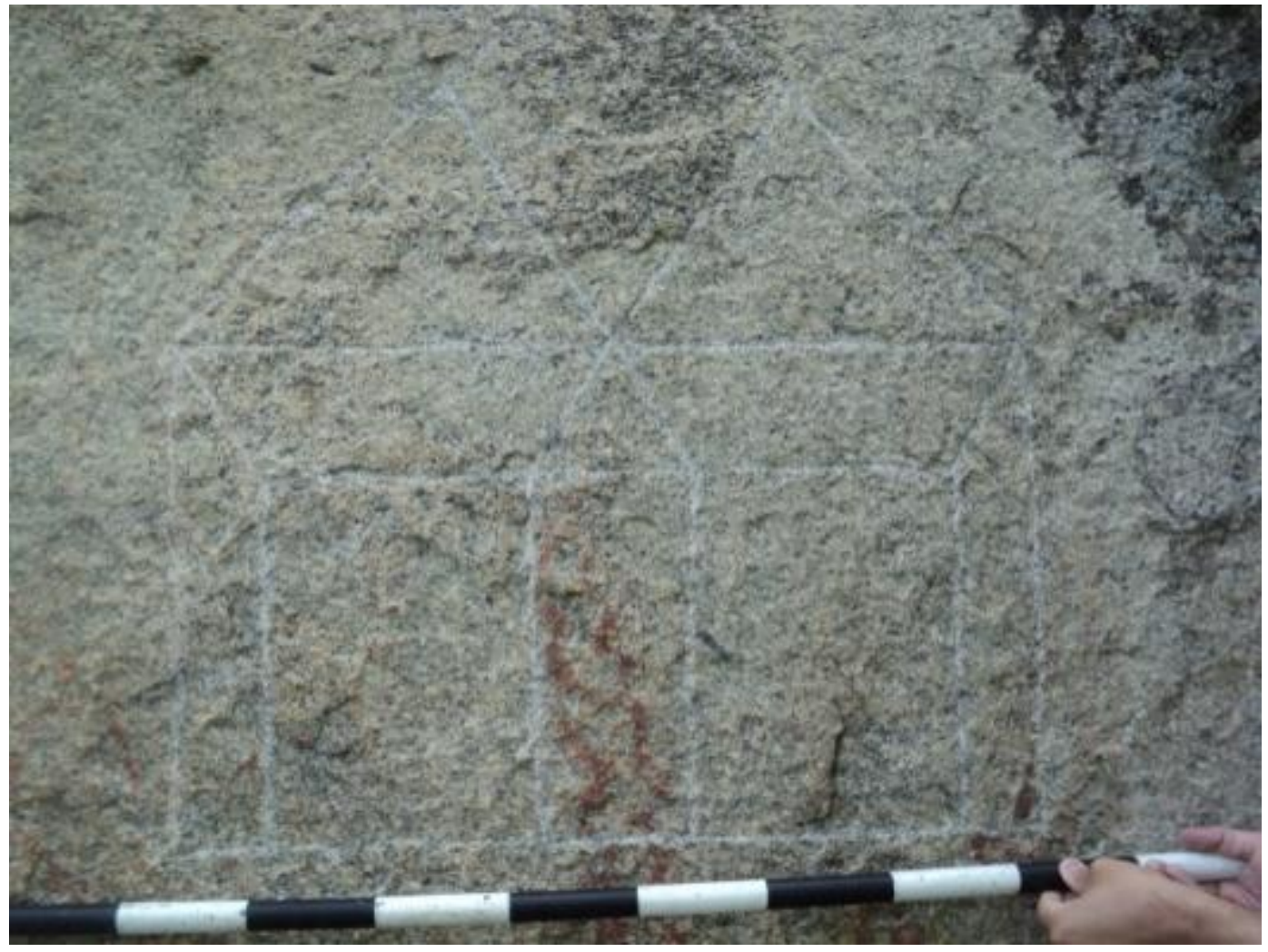


Figura. 5- Área do PE 27-Im, sítio arqueológico caracterizado pela presença de registros rupestres no município de São Caitano-PE. Fonte: Acervo do LA/UFPE, 2013

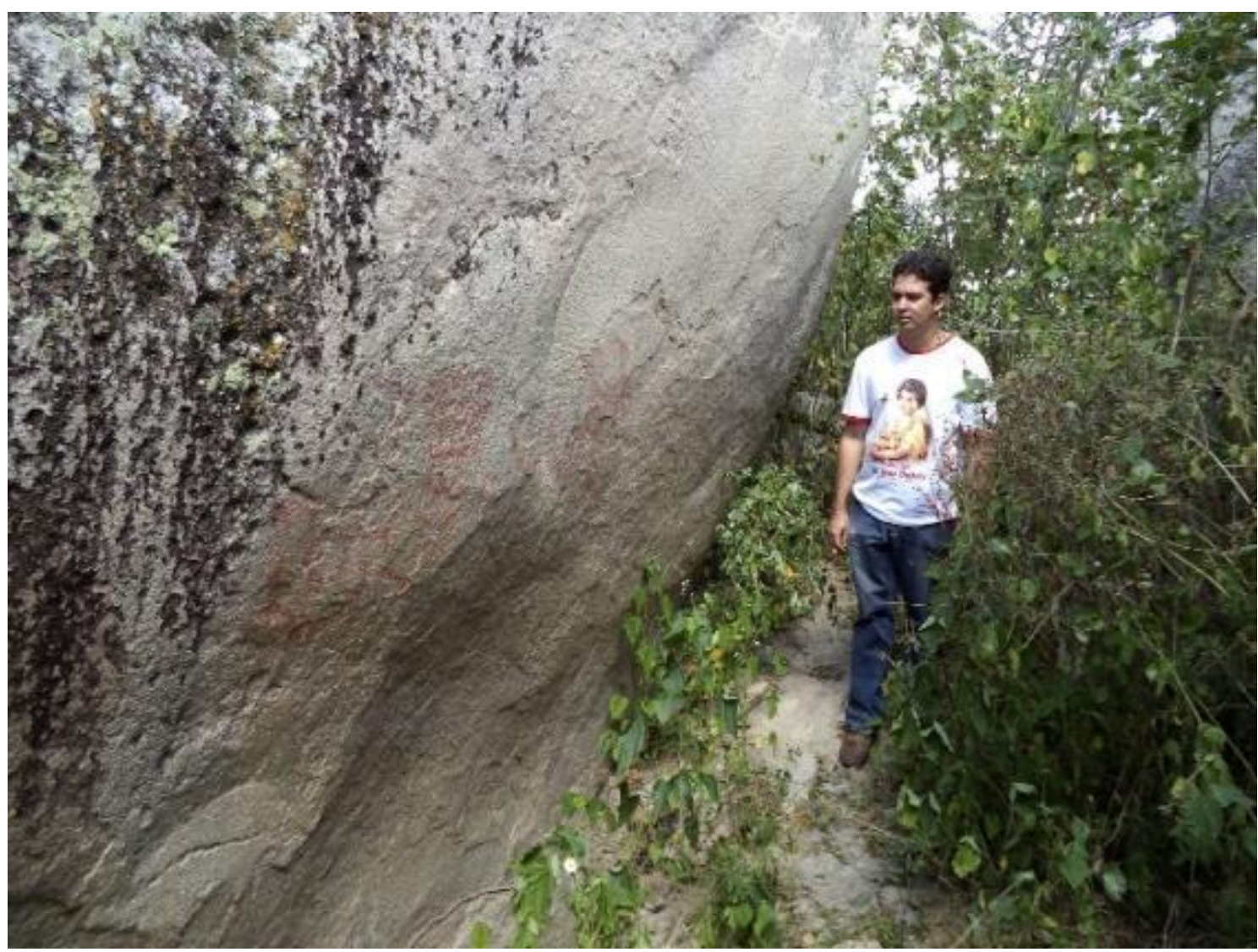

Figura. 6- Detalhe do decalque realizado na década de 70 durante registro do sítio arqueológico PE 27Im no município de São Caitano-PE. Fonte: Acervo do LA/UFPE, 2013.

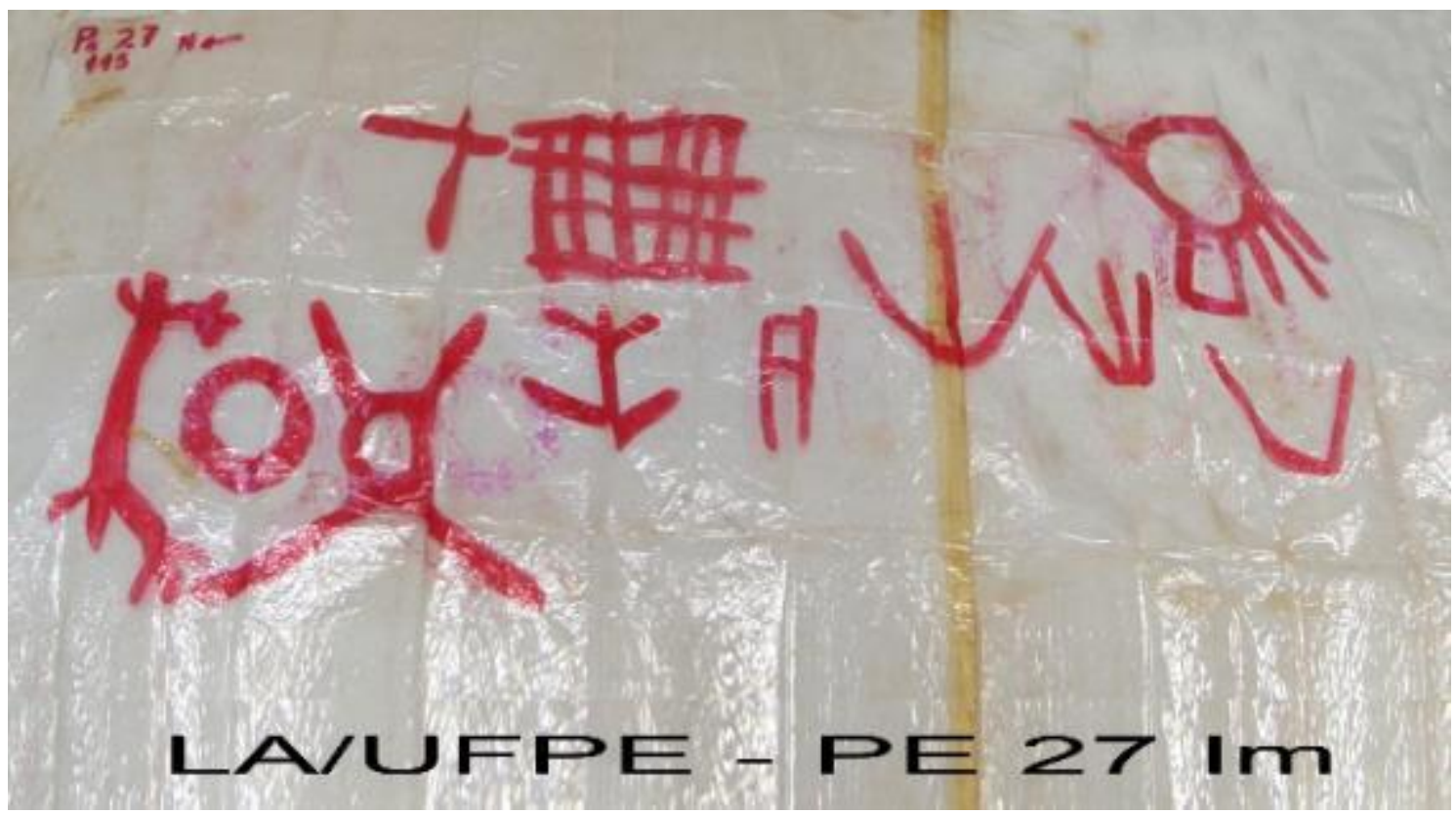


Em relação às evidências líticas, existem registros de sítios e ocorrências isoladas nas regiões do Agreste e Mata pernambucana. No Agreste estão cadastrados na base de dados do IPHAN os sítios PE 7- Ua (CNSA no PE00050), no município de São Caitano, com ocorrência de material lítico lascado (Albuquerque et al., 2013),e o sítio Barra do Timbó (CNSA no PE00326), em Bonito, caracterizado por oficina lítica em afloramento de gnaisse contendo marcas de polimento (Zanettini et al., 2009). Em Panelas, uma ocorrência arqueológica denominada PII02, caracterizada pela identificação de material lítico lascado e percutor em seixo foi assinalada em relatório ambiental (Itep,2011a). Na região da Mata foram identificados os sítios Manuel Ferreira (CNSA no PE00341), em Belém de Maria, e o Engenho Mulatinha (CNSA no PE00343), em Catende. Ambos correspondem a oficina lítica em afloramentos de gnaisse contendo marcas de polimento, localizado no leito do rio Una (Zanettini, Symanski e Moraes, 2009). No município de Barreiros, nas proximidades da foz do rio Una, duas ocorrências isoladas de material lítico foram localizadas (Albuquerque, Lucena e Nogueira, 2008). Tais evidências líticas estão associadas, em grande parte, a grupos nômades caçadores-coletores, assim como, os sítios com registros rupestres.

Além dos sítios rupestres e líticos foram identificadas, em todas as regiões fisiográficas inseridas na bacia do rio Una, ocupações com presença de cerâmica, destacando-se os sítios filiados à Tradição Tupiguarani. Em alguns dos casos, a cerâmica Tupiguarani foi encontrada associada a material lítico e histórico. Esses grupos agricultores ceramistas ocuparam a regiões de norte a sul do Brasil entre 500 e 1800 AD (Martin, 2005).

As datações obtidas em ocupações de grupos ceramistas Tupiguarani correspondem a sítios identificados na Mata Pernambucana, nos municípios de Quipapá (PE 0079 LA/UFPE e PE 0081 LA/UFPE), Água Preta (PE 0493 LA/UFPE) (Figura 7) e Joaquim Nabuco (PE 0646 LA/UFPE), conforme informações contidas no quadro 01. Tais resultados indicam uma ocupação por grupos Tupiguarani nos séculos XII e XVIII. Nesses sítios foram identificados ainda vestígios de material arqueológico histórico compatível com os séculos XIX e XX, correspondendo a ocupações distintas em um mesmo local. Ainda nesta mesorregião foram localizadas ocorrências de cerâmica Tupiguarani nos municípios de Gameleira, Palmares e Barreiros (Albuquerque, Lucena e Nogueira, 2008, Albuquerque, Lucena e Duarte, 2012; Itep, 2011b). Nesse último município os vestígios de cerâmica Tupiguarani ocorrem em região litorânea, na foz do rio Una, associadas também a vestígios históricos. 
Figura. 7- Área do sítio PE 0493 LA/UFPE identificado no terraço do rio Una, em Água Preta-PE, durante acompanhamento arqueológico das obras de duplicação da BR-101. No canto direito da imagem, vestígios cerâmicos Tupiguarani identificados durante as escavações. Fonte: Acervo Laboratório de Arqueologia da UFPE, 2008.

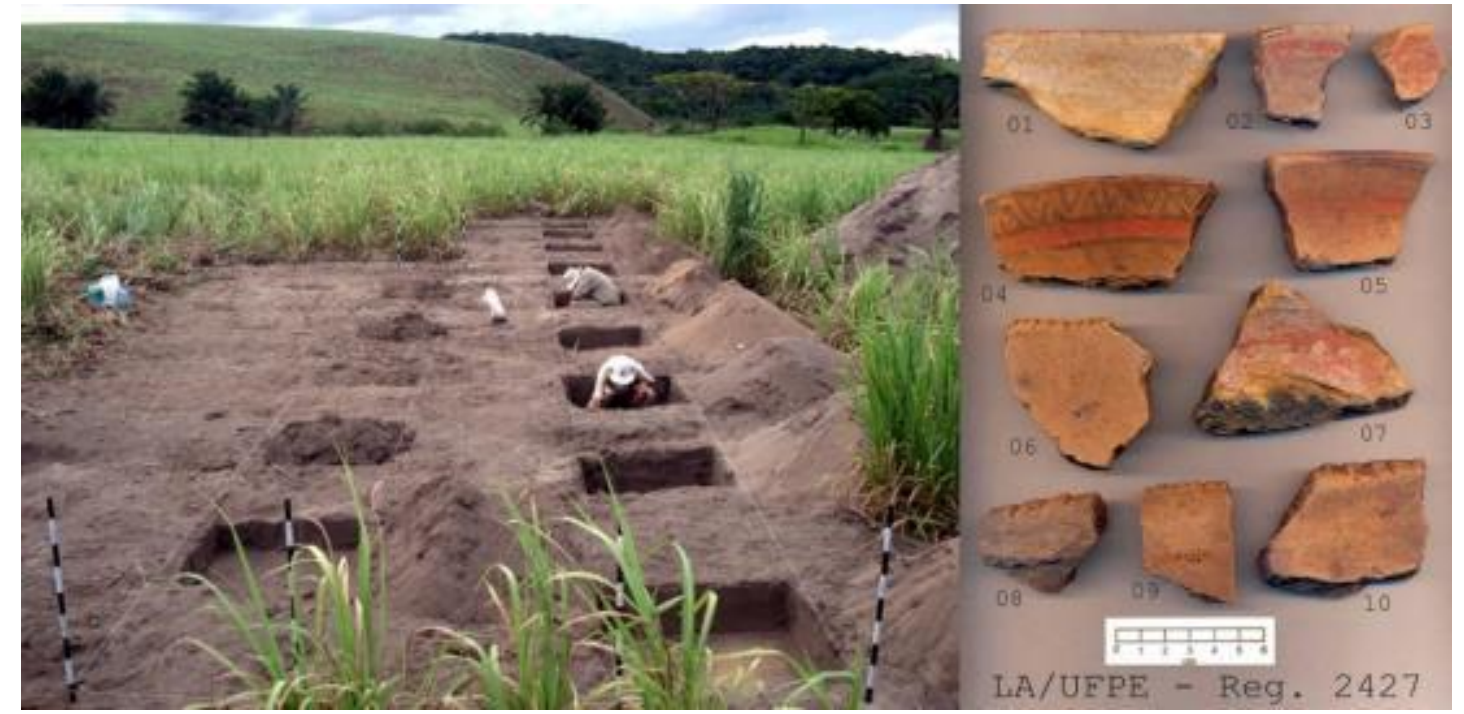

Na região do Agreste foram identificados registros de sítios Tupiguarani nos municípios de Panelas, sítio PE 32 - Ua (CNSA no PE00030), e Bonito, PE 0685 LA/UFPE, PE 0691 LA/UFPE OI, PE 0695 LA/UFPE (ITEP, 2011b). Em relação a presença dos grupos da Tradição Ceramista Tupiguarani na região do agreste e sertão de Pernambuco, Albuquerque (1983-1984), em estudos relativos a grupos horticultores ceramistas dessa Tradição, constatou que na região semiárida a ocupação não ocorreu de forma isolada. Os vestígios identificados denotaram uma ocupação densa, bem distribuída, evidenciando adaptação cultural àquela região fisiográfica, o que não seria compatível com o modelo de ocupantes de Floresta Tropical, que habitavam regiões de mata úmida, aos quais os ceramistas Tupiguarani estavam inseridos. O mesmo trabalho apresenta ocupações desses grupos em todas as regiões fisiográficas de Pernambuco, apresentando datações de 510+/-150 AP (BaH-1086-A)e 2130 +/-400 AP (BaH-1085-A)na região da zona da mata. A última datação apresentada corresponde a um caso isolado, sendo temporariamente desconsiderada, segundo Albuquerque (1991), que situa a maior parte das datações obtidas desta Tradição, entre 1250 e 1650 AD.

A Tradição Ceramista Aratu corresponde a outra tradição existente na região em estudo, caracterizada por urnas funerárias simples, com formato piriforme, que nunca ocorrem de forma isolada. Os solos desse tipo de ocupação apresentam grande espessura de refugo e em vastas áreas a céu aberto. As datações relativas à ocupação de grupos Aratu estão situadas entre os séculos X e XVII, com base em achados na Bahia, Espírito Santo, Minas Gerais e Goiás (Prous, 1992). A denominação Aratu foi dada em decorrência da identificação de um novo tipo de cerâmica localizada pela primeira vez no sítio Guipe, por Valentin Calderón, na Bahia (Martin, 2005).

O sítio do Cajá ou Chã do Cajá corresponde ao único sítio filiado à Tradição Aratu, identificado na bacia do rio Una. Localizado em área de topo de elevação, na margem do Rio Piranji, na sede do município de São Benedito do Sul, cujo local que está sendo ocupada por moradias. 
Este sítio foi localizado, na década de 1990, durante terraplanagem de estrada de leito natural. Por solicitação da prefeitura, a equipe de arqueologia da Universidade Católica de Pernambuco (UNICAP), coordenada pela arqueóloga Jannette Lima, realizou o resgate de parte de urna funerária em cerâmica, parcialmente destruída pela máquina que fazia a manutenção da estrada. O sítio foi classificado como pertencente à Tradição Aratu onde a pesquisadora relata que, "na Bahia, urnas semelhantes foram encontradas na região ocidental do Rio São Francisco e no Recôncavo, com a datação em torno de 1.000 anos antes do presente, bem como em Palmeira dos Índios, em Alagoas, e no Município de Capistrano, no Ceará" (Unicap, 1997). No local ainda foram encontrados cachimbos pré-históricos.

Em 2011, durante levantamento para elaboração de EIA-RIMA para implantação da Barragem Igarapeba, o local do referido sítio foi documentado por pesquisadores da Arqueolog Pesquisas. A equipe identificou, além dos vestígios Aratu, fragmentos de borda cerâmica filiada à Tradição Tupiguarani. No local foram obtidas informações da população local a respeito de "botijas", durante a construção de residências, e de uma "pedra lisa", provavelmente um artefato lítico polido (Itep, 2011c). A bibliografia arqueológica relata a frequente presença de fragmentos de cerâmica Tupiguarani em ocupações de grupos da Tradição ceramista Aratu (Prous, 1992). Dessa forma, foram identificados dois tipos de tradições cerâmicas distintas, onde apenas estudos na área e a datação do material poderão elucidar a coexistência ou não das ocupações. De forma análoga, no estado da Paraíba, foi identificado o sítio PB0047 LA/UFPE, no município de Pilões, onde foi verificada ocorrência de cerâmica Tupiguarani em sítio onde predomina a cerâmica Aratu. Esse sítio, constituído pela identificação de conjuntos funerários, apresentou datações entre os anos de 1090 e 1290 AD para a cerâmica Aratu; e entre os anos de 1652 e 1712 AD para a cerâmica Tupiguarani (ALBUQUERQUE et al., 2012).

As ocupações das Tradições Ceramistas Tupiguarani e Aratu também foram identificadas com datações do período colonial brasileiro (Prous, 1991; Martin, 2005; Albuquerque, 1991). Na bacia do Una, existem apenas datações Tupiguarani relativas ao período histórico.

Ainda ocorrem registros de sítios cerâmicos com filiação cultural não definida. Tal situação corresponde aos sítios pré-coloniais decorrentes do Projeto de Salvamento arqueológico do Gasoduto Alagoas-Pernambuco (Gasalp), onde constam informações de sítios ocupados por grupos agricultores ceramistas, sem maiores especificações relativas à Tradição. No Leste Alagoano, região que em termos fisiográficos está inserida no mesmo contexto da região da Mata Pernambucana, verificou-se ocorrências de vestígios associados a grupos agricultores ceramistas, no município de Jacuípe, em estudo realizado por Lima (2006) referente aos achados durante pesquisa na área do gasoduto. No mesmo trabalho constam informações desse tipo de registro cerâmico nos municípios de Gameleira, Água Preta e Rio Formoso, em Pernambuco.

A análise dos dados pré-coloniais da bacia do Una resultou na identificação de cronologia que remete a uma ocupação inicial em torno de $2.030 \pm 50$ anos BP, recente se comparada a resultados obtidos em estudos arqueológicos em outras bacias hidrográficas brasileiras, que chegam a cerca de 48.000 anos BP no Piauí (Martin, 2005). Contudo, essa última datação é isolada, estando as datações mais antigas situadas em um período que varia em torno de 
11000 anos BP (Prous, 1992; Schmitz, 2000; Martin, 2005). No território do estado de Pernambuco, as datações mais recuadas correspondem a cerca 11000 anos BP, nos sítios Chão do Caboclo, em Bom Jardim, e na Furna do Estrago, em Brejo da Madre de Deus, regiões do agreste pernambucano (Martin, 2005).

Os dados relativos ao patrimônio arqueológico identificados nesta pesquisa foram utilizados na composição de um mapa de ocorrência de vestígios, a nível municipal, que possibilitou a visualização cartográfica dos dados relativos à ocupação pré-colonial (Figura 8). Não foi possível um maior detalhamento dos registros arqueológicos no interior do território de cada município, devido à dificuldade de acesso às informações relacionadas a localização precisa dos sítios e ocorrências. Nas fichas de registros do CNSA, disponibilizadas em meio eletrônico, não são divulgadas informações relativas a localização do sítio, onde Pardi (2002) ressalta que a reserva de alguns campos foi realizada visando a preservação dos sítios e dos proprietários. Outro fator identificado corresponde a ausência de coordenadas da maior parte dos cadastros realizados em período anterior à utilização do GPS.

Figura. 8- Espacialização dos vestígios pré-históricos identificados nos municípios que integram a bacia do rio Una. Fonte: ITEP, 2014.

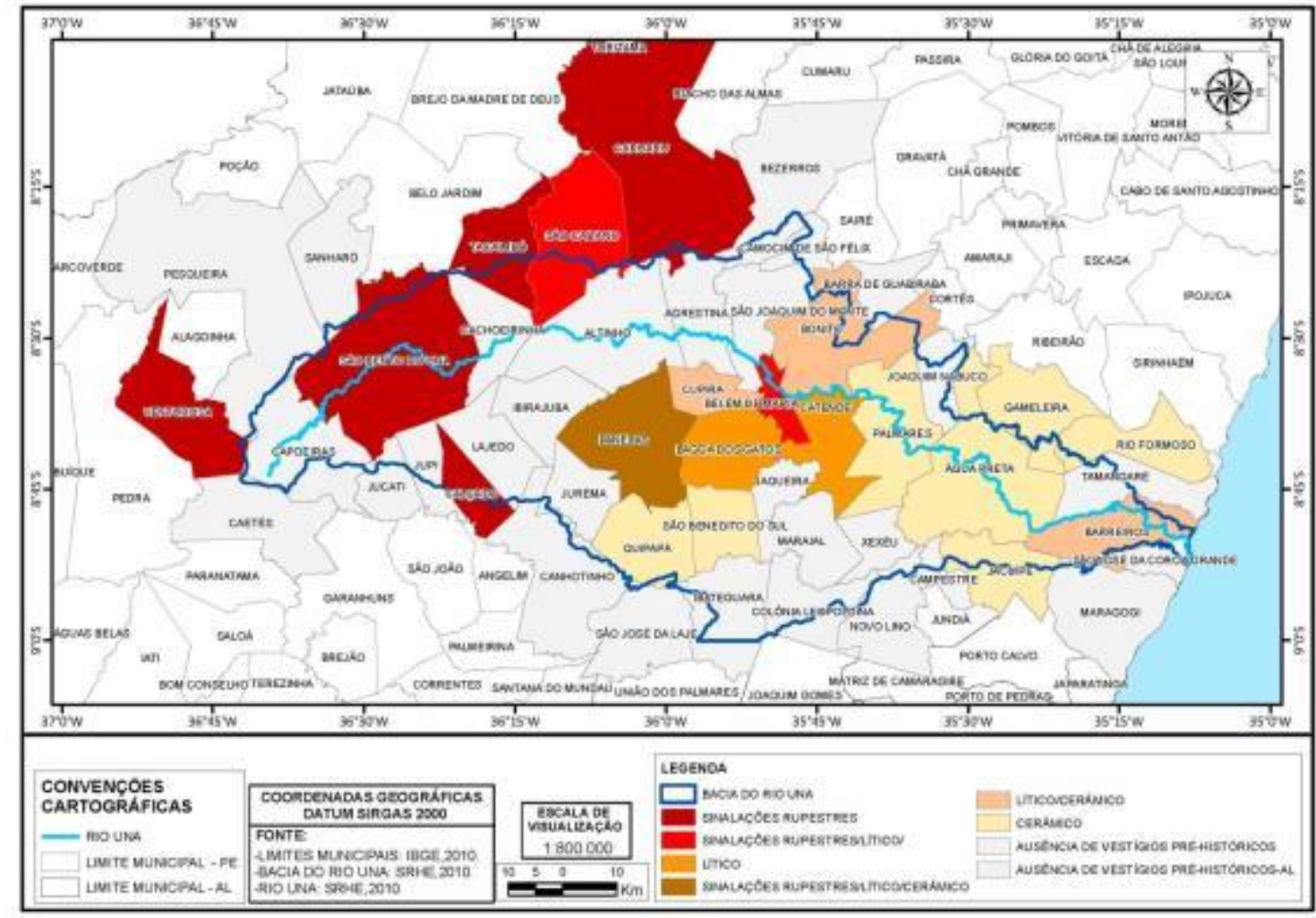

Ocupação histórica

Em relação ao período histórico, foi possível a recomposição de um quadro da ocupação por cronologia, em decorrência de uma maior quantidade de dados obtidos durante 0 levantamento. Em relação à distribuição espacial dos registros, por mesorregiões contidas na 
bacia do Una, 48,5\% (47) dos vestígios históricos foram identificados na região Agreste, seguido de $46,4 \%$ (45) na Mata pernambucana e 5,2\% (5) no Leste Alagoano. Tais registros apresentam cronologia entre os séculos XVII e XX.

A ocupação humana na bacia do rio Una, no período histórico, ocorreu a partir da região litorânea. Após o estabelecimento no litoral, paulatinamente houve penetração para as zonas mais interioranas. As referências históricas relativas a ocupação da foz do rio Una, pelos portugueses, remete ao século XVI, com a instalação de engenhos de açúcar na região e de um aldeamento indígena denominado São Miguel de Iguna ou Una. Segundo artigo publicado nos Anais do Museu Histórico Nacional:

(...) as terras de Alagoas e Sul de Pernambuco sofriam constantes hostilidades dos Caetés, tribo numerosíssima e belicosa que, embora dizimada pelas tropas coloniais, em represália ao assassinato de Dom Pedro Fernandes Sardinha, primeiro bispo do Brasil, ainda continuava bastante forte para atacar-Ihe os colonos e impossibilitar-Ihe lavouras e criação de gado. Esgotados os recursos militares, o governo colonial lembrou-se de ocupar o poder espiritual, rogando a Frei Melchior mandasse seus missionários mais corajosos catequizarem os bravos Caetés no extremo sul da Paróquia de S. Miguel de Ipojuca. Em 1593, seguiam os primeiros religiosos para o Rio Una ou Iguna, armados que andavam com a ilimitada fé em Deus e o zelo das almas. $O$ que a tática bélica das armas lusitanas em vão tentara, conseguia em breve a catequese franciscana. A missão de S. Miguel de Iguna desenvolveu-se de tal sorte que estendeu a catequese até Porto de Pedras-Alagoas, onde em 1597, após a gestão de Frei Melchior, surgiu nova missão, sob a direção de Frei Antônio do Campo Maior, por sinal a primeira penetração catequética historicamente provada em terras alagoanas (Willeke Ofm, 1973, p.31).

O aldeamento, fundado pelos padres franciscanos, passou a ser dirigido pelos jesuítas, em 1625. Com a dominação dos holandeses, foi extinto em 1636, em decorrência da invasão batava, onde a igreja foi saqueada e bastante danificada. $\mathrm{O}$ aldeamento foi restaurado após a expulsão dos flamengos, estando em 1681 reorganizada e novamente administrada pelos franciscanos em 1689, permanecendo até 1742, quando foi entregue aos Carmelitas (COSTA, 1952, vol.3, p. 53). Em 27 de março de 1872 o aldeamento foi extinto pelo governo imperial, através de comunicado do Ministério da Agricultura. As terras pertencentes ao referido aldeamento foram demarcadas para concessão de posses aos indígenas.

A documentação histórica dá conta do intenso contato entre indígenas e europeus na região em fins do século XVI. Rupert (1981, v. II, p. 138) relata que "os franciscanos, cedo tiveram, em Pernambuco, a missão de São Miguel do Iguna ou Una, entre os índios Caetés". Em 1742, a população da Freguesia do Una era composta de "Caboclos de língua geral" (Costa, 1952, vol.3, p.53).

As informações arqueológicas identificadas na região litorânea da bacia do Una, no atual município de Barreiros, são decorrentes de estudo arqueológico voltado para o licenciamento ambiental de empreendimento turístico, denominado The Reef Club. A pesquisa foi realizada 
na margem esquerda do rio Una, onde foi possível a identificação de vestígios pré-históricos e históricos em treze áreas. Os vestígios históricos apresentaram cronologia entre os séculos XVII ao XX. Em algumas ocorrências foram identificados vestígios pré-históricos juntamente material histórico dos séculos XVIII e XIX (Albuquerque et al., 2008), onde apenas a datação da cerâmica pré-histórica poderá definir o contato ou não dos grupos indígenas com os europeus.

Dentre os vestígios identificados durante a execução do mencionado Projeto foram cadastradas, como sítio arqueológico, as ruínas da Igreja de São Gonçalo do Una. Localizada a cerca de $2 \mathrm{~km}$ da área do empreendimento, o sítio foi identificado como PE 0533 LA/UFPE (Figura 9). Construída em pedra, a edificação recebeu, em decorrência de reformas, sucessivos reparos com material de construção do século XX. Abrange uma área de $36 \times 10 \mathrm{~m}$, com paredes apresentando espessura de $70 \mathrm{~cm}$. Em 2008, encontrava-se arruinada, restando apenas às paredes laterais, parte do frontão e do alicerce. Verificou-se ainda a presença de portas e seteiras em suas laterais (Albuquerque, Lucena e Nogueira, 2008).

Figura 9- Ruínas da Igreja de São Gonçalo do Una, PE 0533 LA/UFPE. No canto direito da imagem, detalhe das seteiras na lateral da edificação. Fonte: Acervo Arqueolog Pesquisas, 2008.

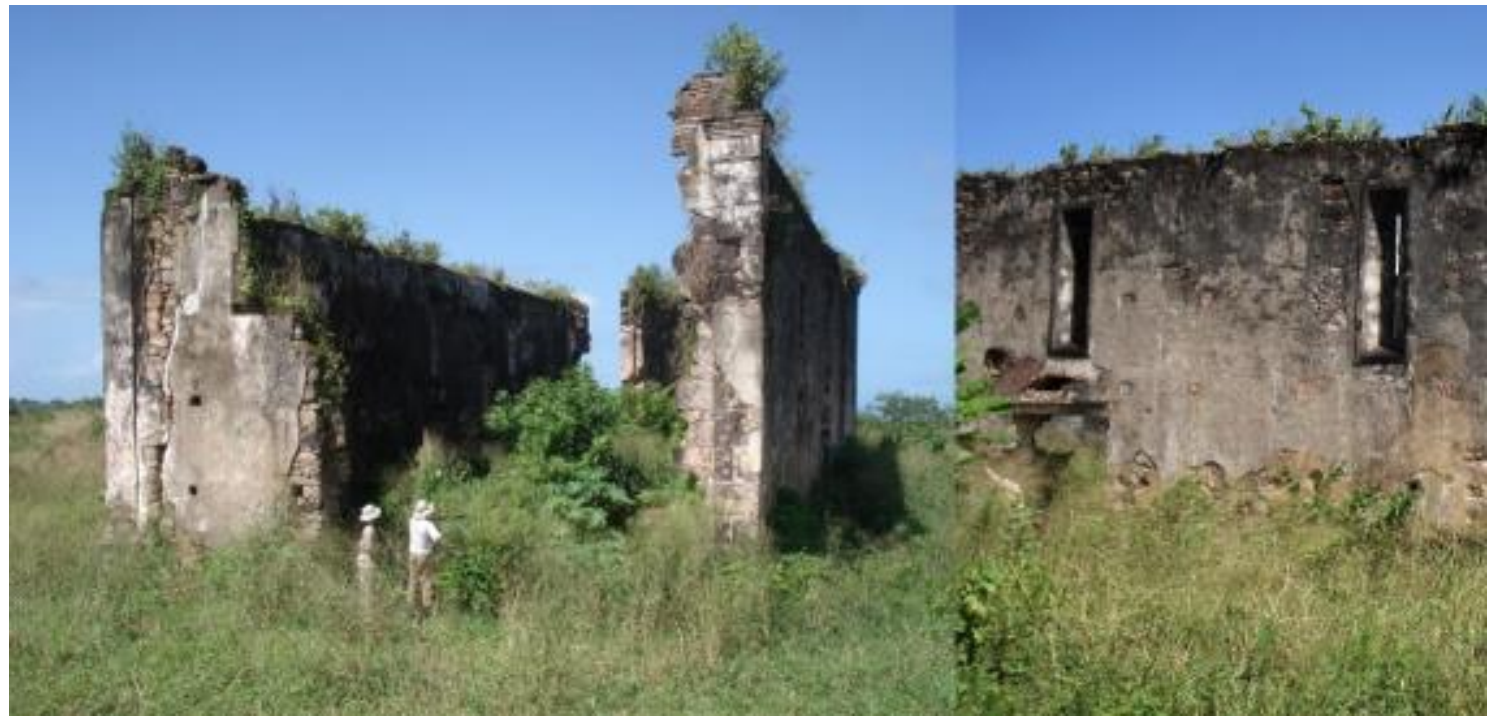

Provavelmente, esta igreja corresponde ao templo religioso da Povoação do Una. Segundo documentação histórica, em localidade próxima ao aldeamento foi fundada a povoação do Una, onde foi erguida uma igreja de São Gonçalo do Una, sob invocação de N. S. da Guia, ficando a região conhecida como freguesia do Una. A localidade é mencionada na documentação histórica com as seguintes denominações: Nossa Senhora da Purificação do Una, Nossa Senhora da Purificação, São Gonçalo Garcia, ou, Freguesia do Una (Costa, 1952). A documentação histórica indica sua localização:

A Povoação do Una está localizada na margem esquerda do rio do mesmo nome, a pouca distância de sua foz no oceano, nos limites da comarca de Barreiros, e a sua antiga matriz, graças à moderna reconstrução que teve em 1873, é um templo espaçoso e de apurada beleza, tanto interna como externamente. A povoação, porém, está em decadência, mas aquém, no 
litoral, junto a barra do rio Una, fica a povoação do Abreu do Una, com uma capela dedicada a São João Batista (Costa, 1952, v. 3, fl.55)

Em carta sobre a situação dos lugares aldeias e comércio de Pernambuco e outras regiões, de 20 de maio de 1630, o neerlandês Adriaen Verdonck, relata que próximo à Porto Calvo está localizado o povoado de nome Una, onde nos arredores se encontra muito gado, plantações de mandioca, milho, fumo, feijão e outros cereais e outras frutas. Informa, ainda, que no local era praticada atividade pesqueira e que, nas proximidades da região, havia 4 ou 5 engenhos de açúcar, estando o povoado a 3 milhas da praia (Mello, 2004).

O Inventário dos engenhos situados entre o rio das Jangadas e o rio Una, elaborado por Willem Schott, em 1636, menciona a existência de dois engenhos na freguesia de Una: o Engenho Nossa Senhora de França, situado a uma milha e um quarto distante da aldeia Una, pertencente a Diogo Paes, e o Engenho São Gonçalo de Una, situado meia milha mais ao oeste da aldeia, pertencente a Estevão Paes. O primeiro movido por água e o segundo por tração animal (MELLO, 2004, p. 69). Tais relatos revelam como se deu a ocupação histórica na região da bacia do Una.

Após a ocupação do litoral, iniciou-se o processo de penetração dos colonizadores europeus em direção à região da zona da mata.Os registros arqueológicos localizados nesta região correspondem, na maior parte dos casos, a fragmentos de cerâmica utilitária, faiança, faiança fina, grés, material de construção, entre outros, compatíveis com os séculos XIX e XX, dispersos na superfície e, com menor frequência, na subsuperfície do terreno.Os fragmentos identificados na subsuperfície, em pouca profundidade, são reflexos da mobilização dos artefatos (mudança do contexto primário) devido a intervenções agrícolas próprias da cultura canavieira, predominante na região (Zanettini e Symanski, 2008; Itep, 2011b; Albuquerque, Lucena e Duarte, 2012). De forma análoga aos resultados obtidos em estudo realizado na bacia hidrográfica do rio Sirinhaém (Albuquerque, Lucena e Nogueira, 2011), os vestígios do período histórico identificados na Zona da Mata da região do Una compartilham um quadro, cuja formação remonta ao início da colonização portuguesa do Estado de Pernambuco, onde terrenos desde o litoral até uma distância de aproximadamente 40 a $50 \mathrm{~km}$, foram predominantemente ocupados por plantações de cana-de-açúcar, contexto este que permanece, em parte, até os dias atuais.

Os registros arqueológicos identificados nos municípios de Água Preta, Barreiros, Catende, Gameleira, Jaqueira, Joaquim Nabuco, Maraial, Palmares, São Benedito, Xexéu (Pernambuco) e Novo Lino (Alagoas) remontam, principalmente, aos séculos XIX e XX (Zanettini e Symanski, 2008; Zanettini, Symanski e Moraes, 2009; Albuquerque, Lucena e Duarte, 2010,2 012). As descobertas arqueológicas desse período, embora ocorram de forma vestigial na maior parte dos casos, são testemunhos da penetração dos produtos ingleses no meio rural. Tais achados colaboram com a busca da compreensão dos hábitos e costumes da sociedade que envolvia a produção açucareira daquela época.

O século XIX foi um período de grandes transformações em todo o mundo, devido à Revolução Industrial, com reflexos indiscutíveis nas sociedades americanas. Desde o início desse período, a sociedade brasileira experimentou fortes mudanças com a transferência da família Real 
portuguesa para o Brasil e a abertura dos portos brasileiros ao comércio internacional, sendo introduzidos novos hábitos na sociedade (Dantas, 1992). No Brasil, as relações políticas e comerciais entre Portugal e a Inglaterra, refletiram nos transportes, indústrias, como também nos modos da sociedade. Data daquela época a necessidade de modernização do parque açucareiro, com a introdução de um novo maquinário, mais produtivo que os antigos engenhos de banguê que, gradativamente foram substituídos pelos engenhos centrais e usinas, no final do século XIX em Pernambuco (Eisenberg, 1997). Relacionados a esse período estão, por exemplo, estruturas históricas de interesse arqueológico como a Casarão do Engenho Verdee vestígios artefatuais (Figuras 10 e 11), em Palmares-PE, registrada com PE 0698 LA/UFPE, durante EIA-RIMA para a implantação da Barragem Serro Azul.

Figura. 10- Casarão do Engenho Verde, sítio histórico de interesse arqueológico, localizado no município de Palmares-PE. Fonte: Acervo Arqueolog Pesquisas, 2011.

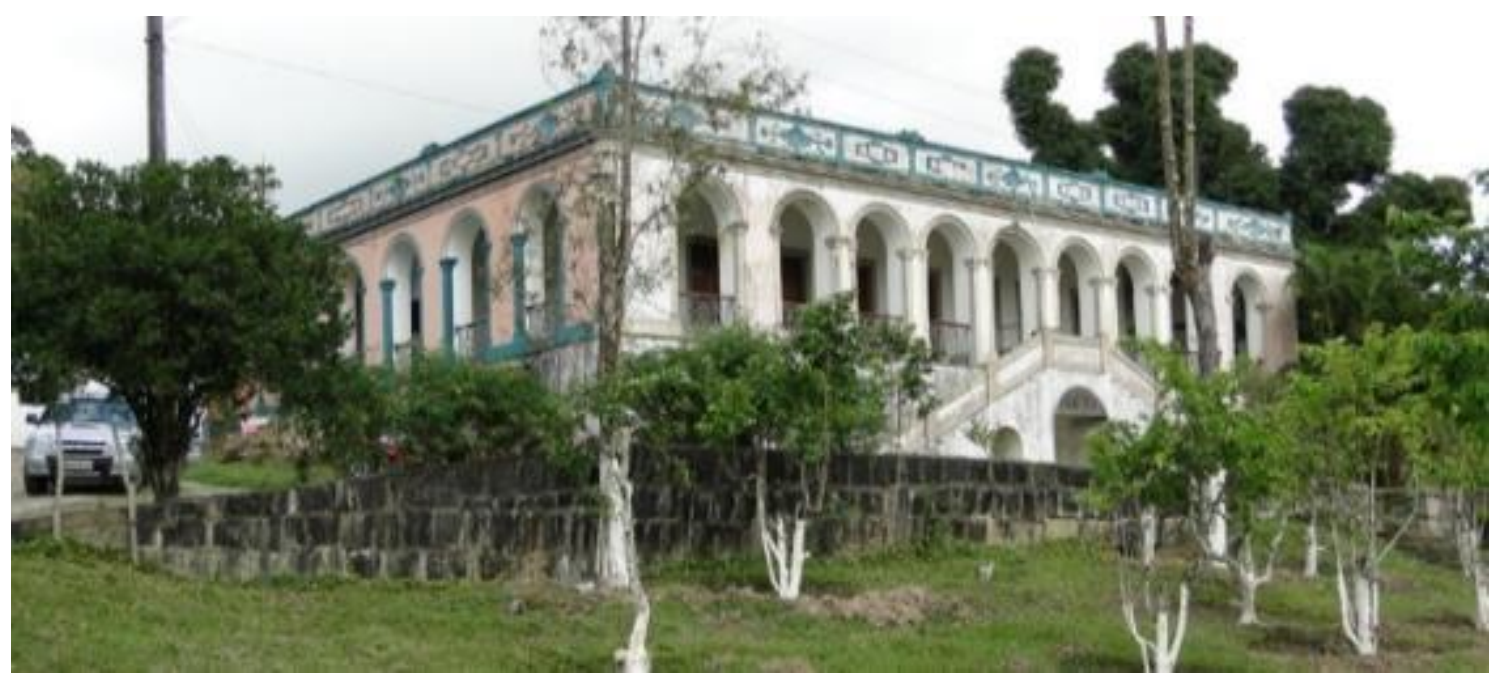

Figura. 11- Fragmentos de faiança fina com cronologia compatível com os séculos XIX e XX, localizadas no entorno do Casarão do Engenho Verde. Fonte: Acervo Arqueolog Pesquisas, 2011.

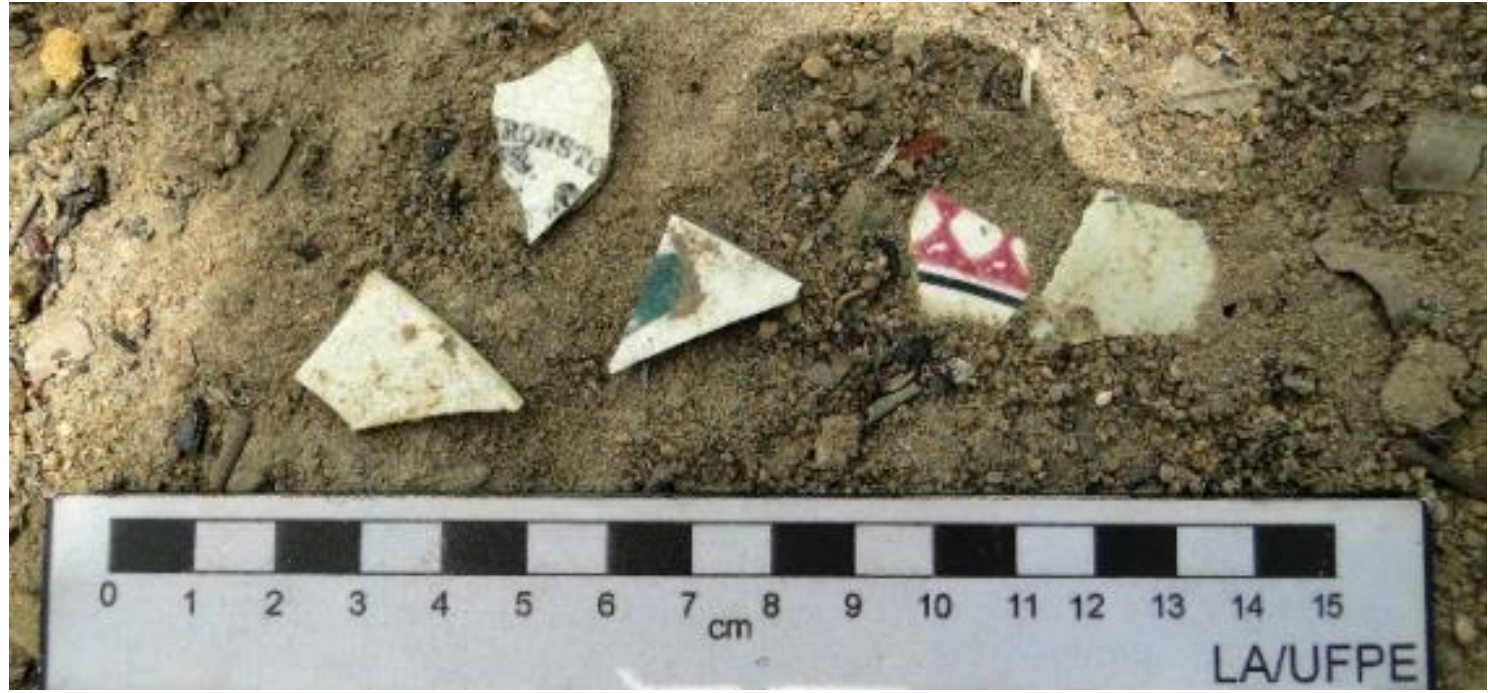

Naquela época, em função da grande incidência de produtos ingleses no Brasil a partir de 1808, a louça doméstica foi um dos produtos que sofreu grande impacto face ao comércio 
inglês, embora a faiança importada de Portugal, desde o século XVIII, já fizesse 'sombra' à produção da cerâmica vermelha fina, de mesa (Albuquerque, Lucena e Nogueira, 2011). Na maior parte dos sítios identificados na bacia do Una predominam fragmentos de louça, dentre outros materiais relacionados ao subsistema alimentar, seguido daqueles associados ao subsistema construtivo.

Na primeira metade do século XX, houve grandes transformações no cenário mundial. Com as duas guerras mundiais, a indústria europeia, grande exportadora mundial, teve que voltar a sua produção para atender às necessidades da guerra. Nessa época, o Brasil ao adaptar-se ao novo cenário mundial, abriu novas indústrias ainda que voltadas a atender à demanda nacional. Entre a primeira e segunda metade do século XX, os caminhões começam a substituir os trens e os tratores que começam a operar em maior número nas plantações. As ferrovias foram gradativamente sendo substituídas por estradas e, aos poucos, ocorreu a desativação de muitas das linhas férreas em Pernambuco, que serviam à indústria açucareira (Op. cit., 2011). A implantação das ferrovias interferiu no processo de ocupação de parte do território nordestino, desde meados do século XIX e durante o século $X X$, atuando como ponto de atração de população, principalmente nos seus pontos de parada, ocasionando na instalação de moradias em seu entorno, constituindo um fator importante na criação, reconformação e manutenção de diversas cidades e suas áreas rurais e/ou peri-urbanas (Zanettini; Symanski, 2007).

O estudo arqueológico da linha férrea entre o Cabo (PE) e Propriá (SE) (Zanettini; Symanski, 2008) buscou ressaltar o papel estruturador que a estrada de ferro, atualmente sob a concessão da Companhia Ferroviária do Nordeste. A linha férrea modificou comportamentos tradicionais, impondo novas práticas e discursos, dinamizando núcleos populacionais e, assim, a economia regional. Conformou todo um sistema hierárquico de uso do espaço. Nesse contexto foram registrados nas proximidades da linha férrea, em trecho que integra a bacia do Una, os sítios Jaqueira (JA) (CNSA no PE00332), sítio histórico do século XIX localizado no município de Jaqueira; Joaquim Nabuco I (JNI) (CNSA no PE00355) e Joaquim Nabuco II (JNII) (CNSA no PE00356), sítios históricos do século XIX localizados no município de Joaquim Nabuco; o sítio Frei Caneca (FC), no município de São Bendito do Sul, e o sítio Fundão, em Maraial, em Pernambuco (Zanettini; Symanski, 2007). Ainda, em diagnóstico para construção da Barragem Igarapeba, em São Benedito do Sul, foi identificado o sítio Água Fria, identificado como PE 0699 LA/UFPE (Itep, 2011c), associado a unidade habitacional e produtiva nas proximidades da linha férrea.

Dos vestígios identificados nas proximidades da linha férrea, até o momento, apenas o sítio Fundão foi possível o resgate de maiores informações através do relato da população local. A propriedade onde foram identificados os vestígios arqueológicos pertencia a Antônio Esteves de Azevedo, que exercia um cargo de chefia na rede ferroviária em meados do século XX, existindo no local uma unidade habitacional, do mesmo período, onde habitavam moradores de engenho, que praticavam agricultura de subsistência e o corte da cana no período da colheita. Relacionado a esse período foi identificado em Alagoas, no município de São José das Lages, o sítio arqueológico Espalhado (CNSA no AL00260), que corresponde a uma habitação de área rural do século XIX (Zanettini; Symanski, 2008). 
Estruturas históricas relacionadas ao patrimônio ferroviário ainda se encontram preservadas em algumas áreas urbanas, como as estações ferroviárias de São Benedito do Sul, Catende e Palmares, em Pernambuco. A maior parte dessas estações assumiram outros usos como unidades de ensino, secretaria de cultura e museu. As que não são utilizadas estão em precário estado de conservação, a exemplo da estação de Igarapeba, em São Benedito do Sul. Outras preservam a denominação da localidade, como o caso de Peri-Peri, estação que existiu entra a cidade de São Benedito do Sul e o distrito de Igarapeba.

Na mesorregião do Agreste, os vestígios identificados remetem a ocupações dos séculos XIX e XX. Tal região apresenta áreas com microclima que se assemelha à região de Zona da Mata, são os chamados Brejos de Altitude, nesse contexto fisiográfico distinto foram identificadas evidências arqueológicas nos municípios de Barra de Guabiraba, Bonito, Altinho, Cupira e Lagoa dos Gatos. Esta região é favorável ao cultivo de cana-de-açúcar e café, onde ocorre ainda criação extensiva de gado. Em paisagem típica do agreste, onde não há condições favoráveis para o cultivo da cana, foram identificados vestígios históricos nos municípios de Lajedo e Pesqueira. Nesta região, a penetração do colonizador ocorreu de forma tardia, sendo uma região onde predomina fazendas de criação de gado.

Da mesma forma dos vestígios pré-coloniais, os dados coletados possibilitaram o mapeamento dos vestígios históricos identificados nos municípios que integram a bacia do rio Una (Figura 12). O mapeamento foi realizado em função do período cronológico dos vestígios encontrados por município.

Figura. 12- Espacialização dos vestígios históricos identificados nos municípios que integram a bacia do rio Una. Fonte: ITEP, 2014

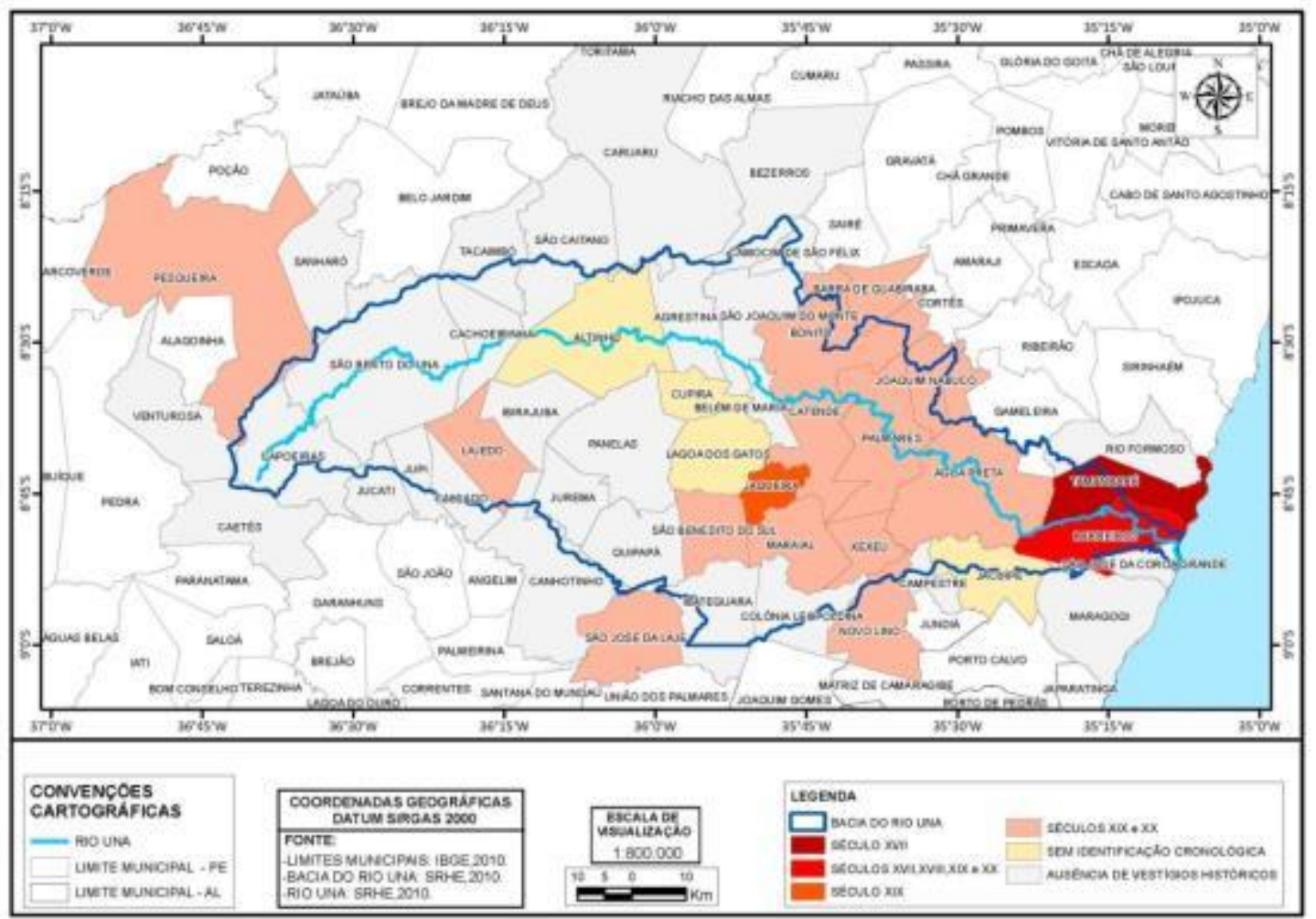




\section{Considerações finais}

O estudo apresentou, à luz dos vestígios arqueológicos, uma caracterização inicial da ocupação arqueológica da bacia do rio Una, constituindo um ponto de partida para a realização de novos estudos, que busquem elucidar aspectos relacionados à presença humana na referida área. Em termos de área ocupada, a bacia do Una é considerada pequena se comparada a rede hidrográfica de outros rios brasileiros, como o São Francisco e o Amazonas. Contudo, tomando como referência o estado de Pernambuco, esta bacia constitui uma das 13 mais relevantes em termos de disponibilidade hídrica.

Durante o levantamento de dados foi possível identificar 149 registros de vestígios arqueológicos, evidenciando o potencial arqueológico da região. A identificação de sítios e ocorrências arqueológicas possibilitou a compreensão de parte da ocupação do território abrangido pela bacia do rio Una. Todavia há que se considerar na análise dos dados que um percentual significativo das evidências materiais ocorre de forma vestigial.

Em relação a ocupação pré-histórica, os dados adquiridos ainda não permitem a montagem de um quadro detalhado da presença do homem em período pretérito. Contudo, os vestígios identificados constituem um ponto de partida para a compreensão da ocupação da área por grupos pré-históricos distintos e em diferentes estágios culturais, ao longo do tempo. Neste estudo foi constatada a presença de registros rupestres nas regiões mais interioranas da bacia, sendo verificada também a ocorrência de vestígios líticos e cerâmicos. Desse período, a cronologia mais recuada identificada corresponde a 2.030 +/- 50 anos BP (Martin, 2005), ou seja, entre anos de 130 e 30 antes da Era Cristã.

Em relação a ocupação histórica, verificou-se um maior registro de sítios desse período com o início dos estudos voltados para atender a demanda de licenciamento ambiental de empreendimentos. Tais vestígios remontam, principalmente, aos séculos XIX e XX. Deste período foram obtidas informações consideráveis relativas ao estabelecimento do colonizador europeu na região do Litoral, onde os vestígios materiais foram contextualizados juntamente com documentação histórica. Na região da Zona da Mata, os vestígios são compatíveis com o ciclo da cana-de-açúcar, onde foi possível a identificação de elementos relacionados a engenhos, usinas, unidades habitacionais e ao sistema ferroviário. Em relação à ocupação histórica na região Agreste, foram identificados vestígios compatíveis com os séculos XIX e, principalmente, $\mathrm{XX}$, onde não foi possível a obtenção de maiores detalhes dada a natureza vestigial dos sítios e ocorrências identificados.

A pesquisa resultou, ainda, no mapeamento das informações identificadas acerca dos registros pré-históricos e históricos dos municípios que apresentam território inserido na bacia hidrográfica do rio Una. Os mapas elaborados possibilitaram, através da visualização cartográfica, uma melhor compreensão da distribuição do patrimônio arqueológico na área pesquisada. Contudo, não foi possível o detalhamento dos dados apresentados em virtude da dificuldade de acesso a informações relativas às coordenadas geográficas de cada registro, principalmente daqueles registrados em período anterior à utilização do GPS. 
Indubitavelmente a Bacia do Una apresenta um grande potencial arqueológico que carece de uma complementação intensiva ao que foi apresentado neste trabalho. A continuidade dos estudos contribuirá de forma significativa para o melhor entendimento da ocupação do solo dessa região, tanto no período anterior à colonização portuguesa da área quanto dos dias atuais.

\section{Agradecimentos}

Laboratório de Arqueologia da Universidade Federal de Pernambuco, Arqueolog Pesquisas, Instituto do Patrimônio Histórico e Artístico Nacional (Iphan) e a Associação Instituto de Tecnologia de Pernambuco (Itep/OS).

\section{Referências}

AGÊNCIA ESTADUAL DE PLANEJAMENTO E PESQUISAS DE PERNAMBUCO (CONDEPE/FIDEM). 2006. Bacia Hidrográfica do Rio Una, GL 4 e GL 5. Série Bacias Hidrográficas de Pernambuco №3. Recife. Disponível em:

$<$ http://www.condepefidem.pe.gov.br/c/document_library/get_file?p_I_id=78673\&folderld=141847\&n ame=DLFE-11996.pdf $>$. Acesso: 21 abr. 2014.

AGÊNCIA PERNAMBUCANA DE ÁGUAS E CLIMA (APAC). 2014.Bacias Hidrográficas: Rio Una. Disponível em:<http://www.apac.pe.gov.br/pagina.php?page_id=5\&subpage_id=23>. Acesso: 21 abr. 2014.

AGUIAR, A. A Tradição Agreste: estudo sobre a arte rupestre em Pernambuco. 1986. Revista CLIO Revista do Curso de Mestrado em História. Editora da Universidade Federal de Pernambuco, Recife, n. 8, série arqueológica n. 3, p.7-98.

ALBUQUERQUE, M. Horticultores pré-históricos do Nordeste. 1983-1984.Arquivos do Museu de História Natural. Belo Horizonte, v. 8/9, p. 131-134.

ALBUQUerQUE, M. Ocupação Tupiguarani no Estado de Pernambuco. 1991. Revista CLIO - Revista do Curso de Mestrado em História da UFPE. Recife, série arqueológica, n. 4, p. 115-116 [Número extraordinário dedicado aos Anais do I Simpósio de Pré-história do Nordeste Brasileiro, Recife].

ALBUQUERQUE, M; ALVES, C. 1983. O sítio arqueológico de Quipapá (PE 79-PIm): contribuição ao estudo da tradição Tupiguarani no Nordeste do Brasil. Boletim do Departamento de História da UFPE. Recife,

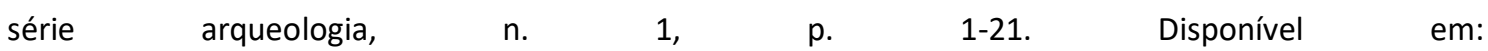
<http://www.brasilarqueologico.com.br/publicacoes.php>. Acesso em: 22 fev. 2015.

ALBUQUerQUe, M.; LUCENA, V.; DUARTE, M.2010. Programa de Prospecção e Resgate Arqueológico do Projeto de Adequação e Aumento da Capacidade Rodoviária da BR-101 NE, BA/PE - Relatório Final. Laboratório de Arqueologia da UFPE, Recife. 
Albuquerque, M.; LUCENA, V.; DUARTE, M. 2012. Projeto de Monitoramento e Salvamento Arqueológico das obras de "Adequação da Capacidade rodoviária da BR-101, trecho Natal/RNPalmares/PE”. Relatório Final. Laboratório de Arqueologia da UFPE, Recife, 2 v.

ALbUQUerque, M.; LUCENA, V; NOgUEIRA, R. 2008. Relatório Final do Programa de Resgate Arqueológico na área do Empreendimento The Reef Club, na Praia do Porto, PE. Arqueolog Pesquisas, Camaragibe, 2 v.

ALbUQUeRQUE, M.; LUCENA, V; NOGUEIRA, R. 2011. Programa de Prospecção e Resgate Arqueológico na área da PCH Pedra Furada - Relatório Final. Arqueolog Pesquisas, Camaragibe, 2v.

ALbuquerque, M; LUCENA, V; UCHÔA, S; NOGUEIRA, R. 2012. Catálogo preliminar do material arqueológico do Sítio PB0047 LA/UFPE, Pilões - PB: Conjuntos Funerários selecionados para exposição no Museu Arqueológico. Arqueolog Pesquisas, Camaragibe.

ALBUQUERQUE, M; LUCENA, V; UCHÔA, S; NOGUEIRA, R. 2013. Estudo de Impacto sobre o Patrimônio Cultural concernente as obras de Duplicação e Restauração da Rodovia BR-423, Subtrecho: Entr. BR-232 (B) (São Caitano), Entr. PE-149/170/180 a Entr. BR-424/PE-218 (Garanhuns), segmento km 18,2 ao km 98,4. Arqueolog Pesquisas, Recife.

Albuquerque, R. T. D. B.; GALVÍNCIO, J. D.2010. Cenários de Mudanças Climáticas na Bacia Hidrográfica do Rio Una - Pernambuco. Revista Brasileira de Geografia Física. Recife, v. 3, n. 2, p.48-54.

AMARAL, M. P. V. Os sítios de registros rupestres em Buíque, Venturosa e Pedra (PE) no contexto da geopaisagem.2007. Dissertação (Mestrado) - Universidade Federal de Pernambuco. Centro de Filosofia e Ciências Humanas, Programa de Pós-graduação em Arqueologia, Recife.

BRASIL. Lei Federal 3.924, de 26 de julho de 1961. Dispõe sobre os monumentos arqueológicos e préhistóricos. Diário Oficial [da] República Federativa do Brasil, Brasília, DF, 27 jul. 1961.

BRASIL ARQUEOLÓGICO. 2015. Projetos. Arqueologia Pré-histórica. Grupos Ceramistas. Tradição Tupiguarani. Mapa de distribuição. [Site da equipe do Laboratório de Arqueologia da UFPE]. Disponível em: http://www.brasilarqueologico.com.br/tupi-mapa.php. Acesso: 03mar. 2015.

BRITO, F. P. 2011.Análise de gravuras rupestres pré-históricas das bacias hidrográficas do Espinharas/ Sabugi / Quipauá-Barra Nova no Seridó ocidental-RN. Dissertação (Mestrado) - Programa de Pósgraduação em Arqueologia. Centro de Filosofia e Ciências Humanas. Universidade Federal de Pernambuco. Recife.

CALDARELLI, S. B. 1991. A degradação do patrimônio arqueológico como consequência da construção de usinas energéticas em bacias hidrográficas: uma reflexão crítica sobre a reversibilidade do processo. In: 3 NCONTRO NACIONAL DE ESTUDOS SOBRE O MEIO AMBIENTE. Anais... UEL, Londrina, v.1, p.72-79.

CALDARELLI, S. B.2012. O Patrimônio Arqueológico na Avaliação Ambiental Integrada de Bacias Hidrográficas. In: 2a CONFERÊNCIA DA REDE DE LÍNGUA PORTUGUESA DE AVALIAÇÃO DE IMPACTOS E $1^{\circ}$ 
CONGRESSO BRASILEIRO DE AVALIAÇÃO DE IMPACTO. ASSOCIAÇÃO BRASILEIRA DE AVALIAÇÃO DE IMPACTOS - ABAI. Anais... São Paulo.

COSTA, F. A. P. Anais Pernambucanos. 1952. Recife: Arquivo Público Estadual, vols. 3;8.

DANTAS, N. B. 1992. Entre coquetes e chicos-machos: uma leitura da paisagem urbana do Recife na primeira metade do séc. XIX; Dissertação (Mestrado em História), Universidade Federal de Pernambuco, Recife.

EISENBERG, P. 1977. Modernização sem Mudança. Rio de Janeiro: Paz e Terra.

HODDER, I.; ORTON, C. 1990. Análisis espacial enarqueología. Barcelona: Editorial crítica.

INSTITUTO DE TECNOLOGIA DE PERNAMBUCO - ITEP. UNIDADE GESTORA DE PROJETOS BARRAGENS DA MATA SUL; LABORATÓRIO DE ENGENHARIA E CONSULTORIA LTDA. - LENC.2011a.Estudo de Impacto Ambiental- EIA: sistema de controle de cheias da bacia do Rio Una - Barragens Panelas II e Gatos. Recife, v. 2.

INSTITUTO DE TECNOLOGIA DE PERNAMBUCO - ITEP. UNIDADE GESTORA DE PROJETOS BARRAGENS DA MATA SUL. 2011b.Estudo de Impacto Ambiental - EIA: sistema de controle de cheias da bacia do Rio Una: Barragem Serro Azul. Recife, v. 4.

INSTITUTO DE TECNOLOGIA DE PERNAMBUCO - ITEP. UNIDADE GESTORA DE PROJETOS BARRAGENS DA MATA SUL. 2011c. Estudo de Impacto Ambiental - EIA: sistema de controle de cheias da bacia do Rio Una: Barragem Igarapeba. Recife, v. 4.

INSTITUTO DE TECNOLOGIA DE PERNAMBUCO - ITEP. UNIDADE GESTORA DE PROJETOS BARRAGENS DA MATA SUL. 2011d. Estudo de Impacto Ambiental - EIA: sistema de controle de cheias da bacia do Rio Sirinhaém: Barragem Barra de Guabiraba. Recife, v.4.

KASHIMOTO, E. M.; MARTINS, G. R. 2000. Panorama arqueológico da margem direita do Rio Paraná, MS: do povoamento por caçadores-coletores a índios guaranis coloniais. Revista CLIO - Revista do Curso de Mestrado em História. Editora Universidade Federal de Pernambuco, Recife, série arqueológica nำ14, p.299-317.

KASHIMOTO, E. M.; MARTINS, G. R. 2004. Archaeology of the Holocene in the upper Paranal River, Mato Grosso do Sul State, Brazil. Quaternarylnternational. v.114, issue 1, p. 67-86.

LIMA, C. F. M. 2006. Padrão de assentamento em sítios arqueológicos na zona da mata norte de Alagoas e sul de Pernambuco. Dissertação (Mestrado) - Universidade Federal de Pernambuco, Centro de Filosofia e Ciências Humanas, Programa de Pós-graduação em Arqueologia, Recife.

LINO, J. T. 2007. Arqueologia Guarani na Bacia Hidrográfica do Rio Aranraguá, Santa Catarina. 2007. Dissertação (Mestrado) - Programa de Pós-graduação em História, Instituto de Filosofia e Ciências Humanas, Universidade Federal do Rio Grande do Sul. Porto Alegre. 
LUFT, V. J. 1990. A Pedra do Tubarão: Um Sítio da Tradição Agreste em Pernambuco.Dissertação (Mestrado) - Programa de Pós-Graduação em História, Área de Concentração em Pré-História, Universidade Federal de Pernambuco, Recife.

MARTIN, G. 2005. Pré-história do Nordeste do Brasil. Editora Universitária da UFPE, Recife, 4a ed.

MELLO, J. A. G. 2004. Fontes para a história do Brasil holandês: a economia açucareira; CEPE, Recife, 2a ed. Leonardo Dantas Silva (Org.), v. I, [Série 350 anos. Restauração pernambucana].

MORALES, W. F. 2007. Um estudo de Arqueologia Regional no médio curso do rio Tocantins, TO, Planalto Central Brasileiro. Revista do Museu de Arqueologia e Etnologia. São Paulo, v.17, p. 69-97.

PARDI, M. L. F. 2002. Gestão de Patrimônio Arqueológico, Documentação e Política de Preservação. Dissertação (Mestrado Profissionalizante em Gestão do Patrimônio Cultural) -Universidade Católica de Goiás, Vice-reitoria de Pós-graduação e Pesquisa, Instituto Goiano de Pré-História e Antropologia. UCG/IGPA, Goiânia.

RUBERT, A.1981. A Igreja no Brasil: origem e desenvolvimento (século XVI). Pallotti, Santa Maria, v. II. PROUS, A. 1992. Arqueologia Brasileira. Ed. UnB, Brasília.

SCHMITZ, P. I. 2000. Arqueologia do Pantanal do Rio Paraguai. Revista de Arqueología Americana. Issue 21, p.191-214.

UNIVERSIDADE CATÓLICA DE PERNAMBUCO - UNICAP. 1997. Laboratório e Museu de Arqueologia. Ofício 13/97. Referente a pesquisa arqueológica em São Benedito do Sul. UNICAP, Recife, 17 de abril, 1997.

WìLLEKE OFM, Frei Venâncio. 1973. A Primeira Ordem se estabelece no Brasil. Anais do Museu Histórico Nacional. Ministério da Educação e Saúde, Gráfica Editora do Livro, Rio de Janeiro, v. XXIV. Disponível em:

<http://www.docvirt.com/Wl/hotpages/hotpage.aspx?bib=MHN\&pagfis=14863\&pesq=\&url=http://doc virt.com/docreader.net\#>. Acesso:15 mar. 2014.

ZANETTINI, P. E.; SYMANSKI, L. C. P. 2007. Programa de Diagnóstico do Patrimônio Arqueológico e Histórico e Cultural - EF Cia. Ferroviária do Nordeste (CFN) - Trecho 03 - Cabo (PE) a Propriá (SE). Relatório Final. Zanettini Arqueologia, São Paulo.

ZANETTINI, P. E.; SYMANSKI, L. C. P.2008. Programa de Resgate do Patrimônio Arqueológico, Histórico e Cultural - EF Cia. Ferroviária do Nordeste (CFN) - Trecho 03 - Cabo (PE) a Propriá (SE). Relatório Final.Zanettini Arqueologia, São Paulo.

ZANETTINI, P. E.; SYMANSKI, L. C. P.; MORAES, C. A. (Coord.). 2009. Programa de Diagnóstico, Prospecção, Resgate e Monitoramento Arqueológico. Ferrovia Transnordestina. Relatório Final da Etapa de Prospecções Extensivas e Interventivas. Zanettini Arqueologia, São Paulo. 